\title{
Nuclear Criticality Safety Analysis Summary Report: The S-Area Defense Waste Processing Facility
}

by

B. C. $\mathrm{Ha}$

Westinghouse Savannah River Company

Savannah River Site

Aiken, South Carolina 29808

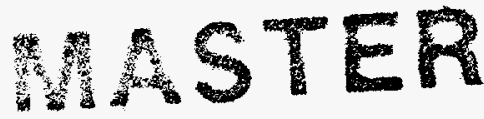

DOE Contract No. DE-AC09-88SR18035

This paper was prepared in connection with work done under the above contract number with the U. S.

Department of Energy. By acceptance of this paper, the publisher and/or recipient acknowledges the U. S.

Government's right to retain a nonexclusive, royalty-free license in and to any copyright covering this paper, along with the right to reproduce and to authorize others to reproduce all or part of the copyrighted paper. 


\section{DISCLAIMER}

This report was prepared as an account of work sponsored by an agency of the United States Government. Neither the United States Government nor any agency thereof, nor any of their employees, makes any warranty, express or implied, or assumes any legal liability or responsibility for the accuracy. completeness, or usefulness of any information, apparatus, product, or process disclosed, or represents that its use would not infringe privately owned rights. Reference herein to any specific commercial product, process, or service by trade name, trademark, manufacturer, or otherwise does not necessarily constitute or imply its endorsement, recommendation, or favoring by the United States Government or any agency thereof. The views and opinions of authors expressed berein do not necessarily state or reflect those of the United States -Government or any agency thereof.

This repor has been reproduced directly from the best available copy.

Available to DOE and DOE contractors from the Office of Scientific and Technical Information. P. O. Box 62, Oak Ridge, TN 37831; prices available from (615) $576-8401$.

Available to the public from the National Technical Information Service, U. S. Deparment of Commeree, 5285 Port Royal Rd., Springfield, VA 22161 


\section{DISCLAIMER}

Portions of this document may be illegible in electronic image products. Images are produced from the best available original document. 
Nuclear Criticality Safety Analysis

Summary Report: The S-Area

WSRC-RP-94-396

Defense Waste Processing Facility

Rev. 0

Page 2 of 52

WESTINGHOUSE SAVANNAH RIVER COMPANY

SAVANNAH RIVER TECHNOLOGY CENTER

Keywords: DWPF, Nuclear

Safety, Nuclear

Criticality.

Retention Time: Lifetime

NUCLEAR CRITICALITY SAFETY ANALYSIS SUMMARY REPORT

THE S-AREA DEFENSE WASTE PROCESSING FACILITY (U)

October 21, 1994

Written by:

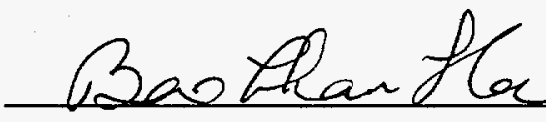

B. C. Ha, 773-A

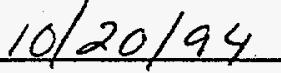

Defense Waste Processing Technology Section (DWPTS)

Date

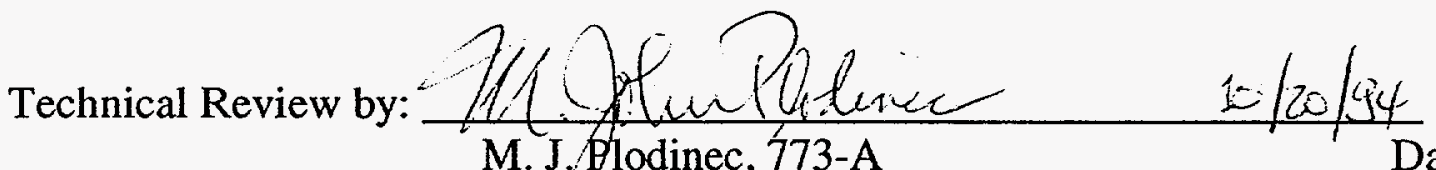

Defense Waste Processing Technology Section

(DWPTS)

Technical Review by:

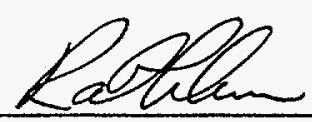

$10 / 2 / 94$

R. W. Rathbun, 786-1A

Date

Criticality and Fire Analysis Section (CFAS) 
Nuclear Criticality Safety Analysis

Summary Report: The S-Area

Defense Waste Processing Facility
WSRC-RP-94-396

Rev. 0

Page 3 of 52

\section{APPROVALS}

Lead Scientist, DWPTS DWPF

Waste Compliance Technology

Manager, DWPTS Advanced Waste

Disposal Tech. \& Waste

Compliance Technology

Manager, Facility Safety

Evaluation Section

Manager, CFAS Criticality

Technology

Manager, HLWM Safety and

Standards Program

Authorized Derivative Classifier Review
Somntharloun 10/21/94

J(R. Harbour, 774-43A Date

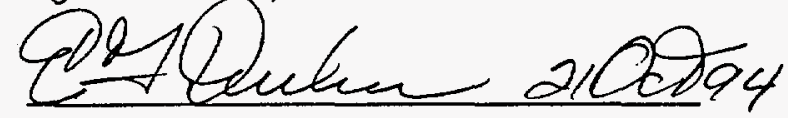

E. F. Duhn, 773-A Date

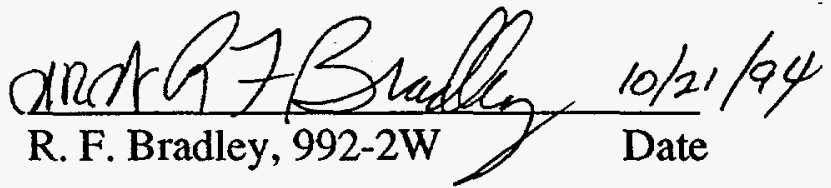

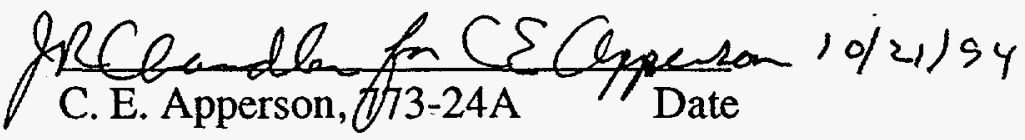

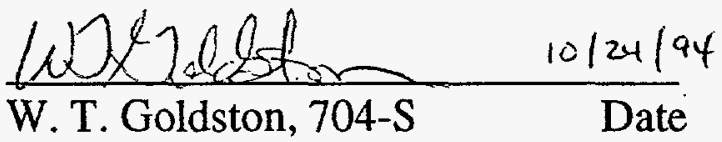




Nuclear Criticality Safety Analysis

Summary Report: The S-Area

Defense Waste Processing Facility
WSRC-RP-94-396

Rev. 0

Page 4 of 52

\section{Summary}

The S-Area Defense Waste Processing Facility (DWPF) can process all of the high level radioactive wastes currently stored at the Savannah River Site with negligible risk of nuclear criticality. The characteristics which make the DWPF critically safe are:

1. abundance of neutron absorbers in the waste feeds,

2. and low concentration of fissionable material.

This report documents the criticality safety arguments for the $\$$-Area DWPF process as required by DOE orders to characterize and to justify the low potential for criticality. It documents that the nature of the waste feeds and the nature of the DWPF process chemistry preclude criticality.

\section{Introduction}

The Savannah River Site (SRS) High Level Nuclear Waste will be vitrified in the S-Area Defense Waste Processing Facility (DWPF) for long term storage and disposal. The fissionable material in the waste has been the result of process losses in separation processes. The fissionable material is currently stored in the tank farm at very low concentrations. Due to the large volume of waste to be processed in one DWPF sludge batch cycle, about 6,500 gallons of sludge and 7,000 gallons of precipitate feed, low concentrations of fissionable material may represent significant quantities. This report demonstrates that criticality poses only a negligible risk in the $S$ Area DWPF process because of the characteristics of the waste and the DWPF process.

The characteristics which make the DWPF critically safe are:

1. abundance of neutron absorbers in the waste feeds,

2. and low concentration of fissionable material.

DOE orders require characterization and justification of the potential for criticality at facilities or processes. The governing documents (DOE Order $5480.24^{1}$, ANSI/ANS $8.1^{2}$, DOE Order $5480.23^{3}$, DOE-STD- 
Nuclear Criticality Safety Analysis

WSRC-RP-94-396

Summary Report: The S-Area

Rev. 0

Defense Waste Processing Facility

Page 5 of 52

$1027^{4}$ ) allow any one of the four following criteria to be used to justify a facility or a process to be in a category of no significant potential for criticality.

1. Total fissionable inventory is less than values in Section 5.2 of ANSI/ANS 8.1.2

2. The physical form of fissionable material precludes criticality.

3. Segmentation or the nature of the process precludes criticality.

4. A Probability Risk Assessment, documented in the SAR, shows the probability of a criticality accident to be less than $10^{-6}$ per year.

The criticality safety arguments for the S-Area DWPF are based on the third criterion.

The following four sections provide arguments for the claim that DWPF process can be operated with negligible risk of criticality.

1. The first section provides background information on the waste characteristics and a description of the DWPF process chemistry. The DWPF is fed by two waste streams from the tank farm: sludge slurry and precipitate slurry. The amount of fissionable material in the precipitate slurry is only a few percent of the amount of fissionable material contained in the sludge feed, and, therefore, can be ignored in areas processing both types of feeds, except for the Late Wash Facility and the Salt Processing Cell.

The uranium and plutonium content of the precipitate feed stream must be examined in the DWPF Late Wash Facility and the Salt Processing Cell before this stream is combined with the sludge stream in the Chemical Processing Cell. The fate of iron and manganese, as neutron absorbers, and fissile material is also determined throughout the DWPF process from the tank farm until the waste is finally immobilized in the borosilicate glass form in the DWPF melter.

2. The second section outlines the basis of the S-Area DWPF criticality safety characteristics. Once it is established that iron 
Nuclear Criticality Safety Analysis

Summary Report: The S-Area

Defense Waste Processing Facility
WSRC-RP-94-396

Rev. 0

Page 6 of 52

and manganese remain with fissile material throughout the entire DWPF process, the safe weight ratio concept developed by Clemmons and Goslen5-6 is then established as the basis of the DWPF criticality safety characteristics. Using the criteria involving safe weight ratios of iron and manganese to fissile material, it is demonstrated that the DWPF operation is always subcritical when processing the current HLW tank inventory.

It is also shown that process areas processing primarily the precipitate feed slurry is also safe due to the chemistry behavior of uranium, plutonium and monosodium titanate in a formic acid solution.

3. The third section details applicable criticality analyses of DWPF process areas which have significant physical and chemical interactions. It investigates potential upset conditions and shows them to be safe against a nuclear criticality with a safety factor of at least five for all materials expected from the first six planned major sludge batches and their associated precipitate slurry feeds.

4. Finally, the conclusions and recommendations are provided.

\section{Background}

\section{Overview of the DWPF process}

Figure 1 shows a schematic diagram of the process to immobilize high level waste (HLW) stored at SRS. The DWPF sludge feed slurry is considered to be well-mixed because of the Extended Sludge Processing (ESP) in the tank farm.

High level waste salt solution is processed in the ITP process to remove cesium-137 and to adsorb strontium on monosodium titanate (MST). Soluble uranium and plutonium are also adsorbed on monosodium titanate. 7 The tetraphenylborate slurry containing potassium and cesium tetraphenylborate precipitates and MST with adsorbed strontium, uranium, and plutonium is then washed in the DWPF Late Wash Facility (LWF) before it is sent to the DWPF Salt Processing Cell (SPC). 
Nuclear Criticality Safety Analysis

Summary Report: The S-Area

Defense Waste Processing Facility
WSRC-RP-94-396

Rev. 0

Page 7 of 52

Figure 1

\section{A Schematic Diagram of the S-Area Defense Waste Processing Facility}

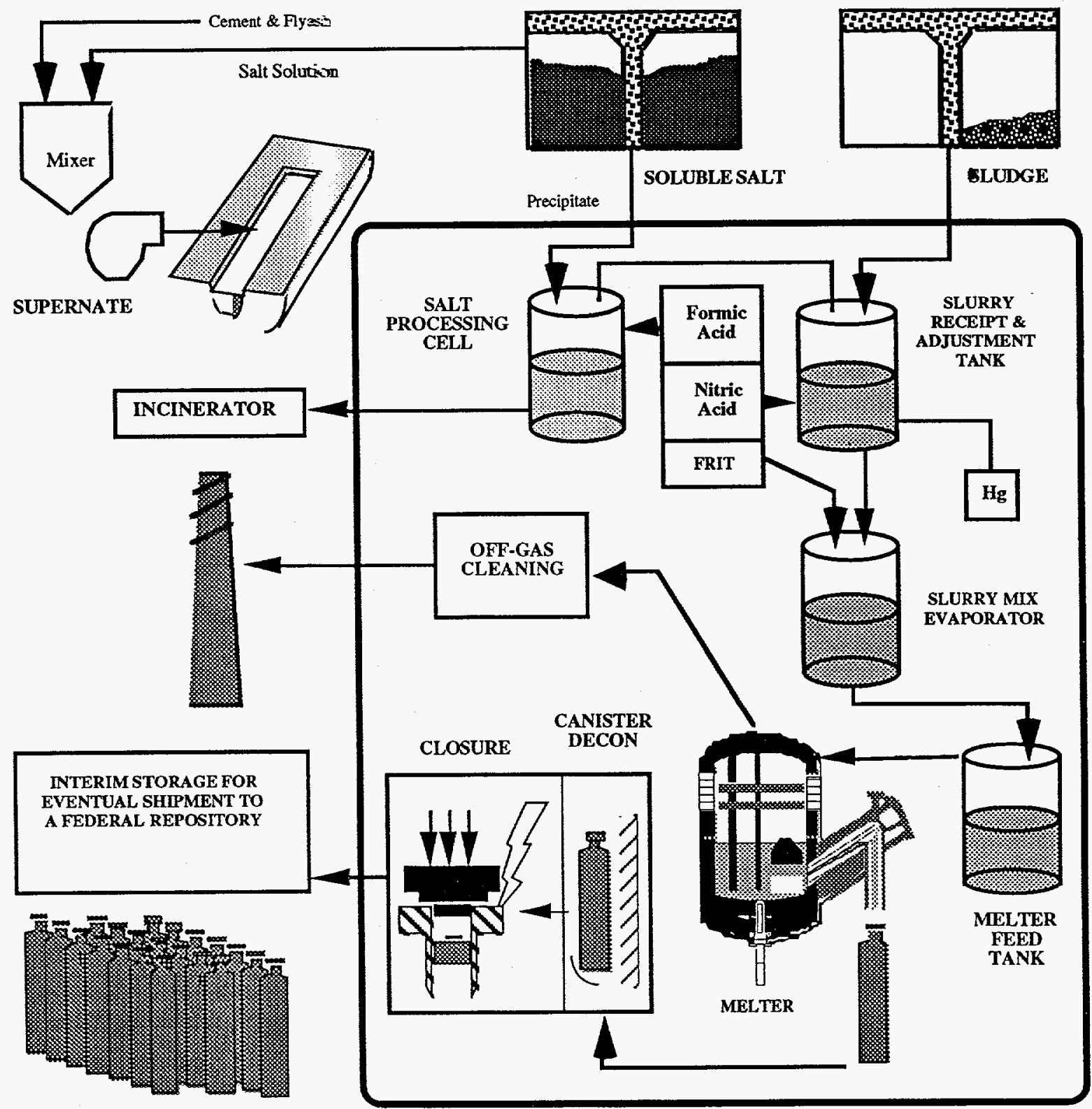

DEFENSE WASTE PROCESSING FACILITY (DWPF) 
In the Salt Processing Cell, the precipitate slurry is first stored in the Precipitate Reactor Feed Tank (PRFT) and then processed in the Precipitate Reactor (PR). In the PR, tetraphenylborate is destroyed by acid hydrolysis reactions to produce benzene and an aqueous phase containing radionuclides.

The sludge feed is slurried, washed, and filtered several times in Tanks 40, 42, and 51 and become homogenized during ESP operation. Alkaline sludge feed is then transferred from the tank farm to the Sludge Receipt and Adjustment Tank (SRAT) in the DWPF Chemical Processing Cell (CPC). The sludge slurry is treated with nitric acid in the SRAT to control the rheological properties of the sludge slurry and to react with several components on the slurry, primarily nitrites, carbonates, and soluble hydroxides.

The Precipitate Hydrolysis Aqueous product (PHA) is combined with the sludge slurry and the borosilicate glass frit in the DWPF Chemical Process Cell (CPC) to produce melter feed. The high level radioactive waste is finally immobilized in a glass matrix contained in sealed stainless steel canisters. Reference 8 contains the most current information on the material balances for the DWPF, and it also shows fissile content in the process streams of the Salt Processing Cell.

To summarize the overall DWPF process operation, there are two HLW feed streams from the tank farm delivered to the S-Area DWPF. The precipitate feed slurry is processed in the Salt Processing Cell to produce the PHA for subsequent SRAT and Melter operations. The sludge slurry is processed in the SRAT, and combined with the PHA. The amount of PHA, or more correctly the amount of soluble and insoluble solids in the PHA, is half of the sludge solids. All of the HLW slurry feeds are combined in the SME with the glass forming frit. The Melter immobilizes all of the HLW feeds in a waste borosilicate glass form.

A detailed discussion of the characteristics of the waste and the DWPF process chemistry, which will be used as a basis for DWPF criticality arguments, is provided in Appendix A. Following is a summary of the behavior of fissile material in the DWPF process streams. 


\section{Fissionable Material}

Of the fissionable isotopes available in the DWPF process, only those which are fissile (i.e. those which can undergo thermal fission such as $\mathrm{U}-235, \mathrm{U}-233, \mathrm{Pu}-239, \mathrm{Pu}-241$ ) are of concern. The process involves aqueous solution and solid slurries maintaining sufficient hydrogen to allow the non-fissile but fissionable isotopes to be ignored.9 This eliminates the need to evaluate the criticality safety impact of many of the fissionable but non-fissile isotopes.

Americium and curium have fissile isotopes and are present in the DWPF feeds. The amount of americium and curium in the HLW is many times less than uranium and plutonium, and the non-fissile isotopes greatly exceed the fissile isotopes. 10 The small mass of these elements entering the waste tanks is distributed throughout a few tanks. The insignificant contribution of americium and curium fissile isotopes compared to those of uranium and plutonium fissile isotopes led to these being ignored in this report. Characterization effort in the tank farm will provide continued confirmation of this assessment of americium's and curium's impact.

The Uranium and Plutonium Content of the Precipitate Process Streams.

There are two different streams of fissionable material entering the S-Area DWPF process in the precipitate feeds: (1) fissile material adsorbed on the monosodium titanate (MST), and (2) fissionable material in the entrained insoluble sludge solids of the salt solution. There is no chemical reaction involving either fissionable material in the entrained sludge or fissile material, primarily $\mathrm{U}$ and $\mathrm{Pu}$, adsorbed on MST in the Late Wash Facility and the Salt Processing Cell. However, during the benzene distillation and subsequent total reflux in the Precipitate Reactor's process cycle, fissile material may be partially desorbed from MST. Following is a discussion of effects of formic acid boiling on adsorbed uranium and plutonium on MST.

A small amount of monosodium titanate containing $2.2 \mathrm{wt} \%$ depleted uranium was boiled in a formic acid solution to simulate the PR reaction cycle. 11 The MST to $90 \%$ formic acid ratio in the experiments 11 was about $15 \mathrm{mg} / \mathrm{ml}$, compared to $65 \mathrm{mg} / \mathrm{ml}$ in a 
typical PR reaction cycle 8 . It was found that about $34 \%$ of the depleted uranium was desorbed from MST after 5 hours of boiling the MST in a formic acid solution. Increasing the boiling time of the experiment to 12 hours did not effect additional desorption of depleted uranium, since only $35 \%$ depleted uranium was desorbed. Three important conclusions were derived from the experimental work.

(1) The depleted uranium desorbed from MST is soluble uranium. It was not a surprise, since uranium adsorbed on MST during the ITP process cycle comes from soluble uranium in the salt solution.

(2) The concentration of uranium in the formic acid solution after experiments was about $5 \mathrm{ppm}$. It was much lower than 25 grams $U$ per liter of saturated solution as estimated from the solubility data of $\mathrm{UO}_{2}$ in formic acid solution. 12 It is an indication that the remaining $U$ is still strongly adsorbed on MST.

(3) Scanning Electron Microscopy analysis confirmed that there is depleted uranium still adsorbed on MST.

Reference 11 also reviewed experimental data from the small scale Precipitate Hydrolysis Process demonstration with radioactive precipitate feed from Tank 48. No soluble plutonium was found in PHA, as none was detected by the Inductively-Coupled Plasma-Mass Spectrometry (ICP-MS) analysis. There was also evidence that no measurable amount of soluble uranium was desorbed from MST.

Ratios of Iron and Manganese to Uranium and Plutonium in the S-Area DWPF Process.

The detailed discussion in Appendix $A$ indicated that there is no chemical reaction separating or isolating fissionable material in the sludge process streams throughout the S-Area DWPF process. All of the fissile materials remain in the sludge solid phase through the entire DWPF processing scheme. Iron and manganese are the two chemical species of interest in the sludge solids, due to their role as neutron absorbers, which will be discussed fully later. There is only 
Nuclear Criticality Safety Analysis

Summary Report: The S-Area

Defense Waste Processing Facility
WSRC-RP-94-396

Rev. 0

Page 11 of 52

one chemical reaction involving manganese in the SRAT, which effectively removes about half of the manganese from the sludge solids into the aqueous solution. There are redox reactions involving iron and manganese in the Melter, but it does not affect the criticality safety characteristics since they still remain with the fissile materials within the glass matrix.

Tank 51 radioactive sludge was processed in a demonstration of the DWPF process in the Savannah River Technology Center's Shielded Cells.13-14 Reference 14 contains more detailed information on the characteristics of the Tank 51 sludge feed and borosilicate waste glass, and is believed to be more accurate simply by the number of samples which were analyzed. Uranium and plutonium elements 14 were used instead of isotopes for comparison with data from reference 13 which did not have isotopic information. The ratios of iron and manganese to uranium and plutonium in the dried sludge solids, which include both the soluble and insoluble solids, and glass, as calculated from the data of references 13 and 14 , show that they remain rather constant throughout this DWPF process demonstration, as follows.

\begin{tabular}{|c|c|c|c|}
\hline 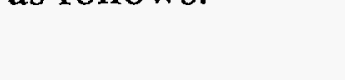 & $\underline{\mathrm{Fe} / \mathrm{U}}$ & $\underline{\mathrm{Fe} / \mathrm{Pu}}$ & $\underline{\mathrm{Mn} / \mathrm{U}}$ \\
\hline Sludge Feed 14 & 9.4 & 3069 & 1.0 \\
\hline SRAT product 13 & 11.1 & -- & 1.1 \\
\hline Melter product 14 & 9.5 & 3545 & 1.0 \\
\hline
\end{tabular}

It is important to note that although the manganese to uranium and plutonium ratios remain essentially the same throughout the DWPF process, only $50 \%$ of $\mathrm{Mn}$ can be counted as neutron absorbers. During the nitric acid addition of the SRAT cycle, up to $50 \% \mathrm{Mn}$ becomes soluble and is no longer in the sludge solids with fissionable material. Under abnormal or upsets conditions, the presence of soluble $\mathrm{Mn}$ or ratio of soluble $\mathrm{Mn}$ to the fissile material (or sludge solids) cannot be guaranteed. Therefore, only the insoluble $\mathrm{Mn}$, which amounts to more than $50 \%$ of the manganese in the sludge feed and is always present throughout the DWPF process, can be counted as a neutron absorber. 
Nuclear Criticality Safety Analysis

Summary Report: The S-Area

Defense Waste Processing Facility
WSRC-RP-94-396

Rev. 0

Page 12 of 52

\section{Basis for the S-Area DWPF Criticality Assessment}

The basis of the sludge processing in the S-Area DWPF criticality safety assessment is based on the work of Chandler, Clemmons, and Goslen on the tank farm HLW criticality safety characteristics. 5-6,1517 Williamson provided calculations and criticality assessments for DWPF process areas, which have major chemical and physical interactions. ${ }^{18-19}$

The criticality safety characteristics of the precipitate feed streams and subsequent salt processing will be considered first as a special case in the Late Wash Facility and Salt Processing Cell. The basis for the DWPF criticality safety analysis will then be established for the sludge feed slurry and subsequent sludge processing, which covers the entire DWPF process, excluding the Late Wash Facility and the Salt Processing Cell.

\section{DWPF Precipitate Feed}

There are two different streams of fissile material entering the Sarea DWPF process in the precipitate feeds: (1) fissile material adsorbed on the monosodium titanate (MST), and (2) fissile material in the entrained insoluble sludge solids of the salt solution. It is worth noting that the fissile material adsorbed on MST during the ITP process cycle comes originally from soluble fissile material. The maximum loading of fissile material on MST has been demonstrated to be safe for an infinite system. 15 The remaining soluble fissile material not adsorbed on MST in the original salt solution will be washed back to the tank farm during the washing and filtering cycles of the ITP process.

The precipitate slurry feeds from the tank farm to the DWPF are inherently safe with respect to nuclear safety and nuclear criticality. Adsorbed fissile material on the monosodium titanate solids is very dilute. Furthermore, the titanate solids and tetraphenylborate salts function as neutron absorbers. Chandler 15 demonstrated that the potential for criticality due to adsorption of fissionable material by MST is incredible. He analyzed criticality safety in ITP by two bounding conditions: (1) the minimum safe ratio of MST to fissionable material, and (2) the maximum fissionable material 
Nuclear Criticality Safety Analysis

Summary Report: The S-Area

Defense Waste Processing Facility
WSRC-RP-94-396

Rev. 0

Page 13 of 52

adsorption capacity of the MST. The first bounding condition was evaluated using calculations. The second bounding condition was determined by experimental analysis.

Reference 15 documented that the maximum loading of uranium and plutonium on monosodium titanate (MST) is below the individual infinitely safe limits for plutonium and uranium. Essentially, Chandler 15 demonstrated that fissile material adsorbed on MST is safe for an infinite system. Therefore, as long as the fissile material is adsorbed on the MST substrate, the precipitate feed and its subsequent process streams are subcritical.

The fissile material in the entrained insoluble sludge solids repmains unchanged throughout the In-Tank Precipitation process cycle. The entrained insoluble solids are limited to $400 \mathrm{mg} / \mathrm{L}$ by the process requirement of the In-Tank Precipitation process. 20 The ITP crossflow filter will easily be plugged and require more frequently maintenance if the entrained insoluble solids exceed $400 \mathrm{mg} / \mathrm{L}$ limit. Consideration of the fissile material in the entrained insoluble sludges is the same as those that applied to the DWPF sludge process stream. Basically, the potential of a nuclear criticality associated with a sludge solid containing fissile material is negligible due to the abundance of iron and manganese, which are inherent in the sludge, and the low concentration of fissile material. The entrained insoluble sludge solids stay basically intact throughout the Salt Process Cell's reaction cycle.

Criticality Safety Characteristics of Precipitate Process Streams in the Late Wash Facility and the Salt Processing Cell

Reference 18 examined the criticality safety of the DWPF Late Wash Facility and Salt Processing Cell. It concluded that the material processed in the Late Wash Facility and the Salt Processing Cell remains safe from a nuclear criticality because of the following reasons:

(1) The adsorbed fissile material on MST is safe due to the abundance of the neutron absorbing titanium in MST. 
Nuclear Criticality Safety Analysis

Summary Report: The S-Area

Defense Waste Processing Facility
WSRC-RP-94-396

Rev. 0

Page 14 of 52

(2) For fissile material desorbed from MST during the PR reaction process cycle, it is safe because they become soluble in the PHA. The high hydrogen-to-soluble-fissile ratio in the solution prevents a nuclear criticality.

(3) Furthermore, the fissile material content in one precipitate batch is low enough that a critical mass does not accumulate in tanks in the Late Wash Facility and Salt Processing Cell.

Other neutron absorbers such as the prevalent boron, which is the main chemical reagent in the precipitate process stream, also mitigates against a nuclear criticality.

Following is a further discussion of the above last two characteristics of the salt process chemistry in the Late Wash Facility and the Salt Processing Cell in the DWPF. A complete discussion of the first basis can be found in references 15,18 , and 21 . It is important to note that uranium does not desorb from MST until the acid hydrolysis reaction of tetraphenylborate salt has taken place in the Precipitate Reactor in the Salt Processing Cell.

The following estimate of the amounts of fissile material is lower than those reported in reference 18 , which is based on the current flowsheet of the referenced DWPF coupled operation 8 . The information on adsorbed uranium and plutonium during ITP has not yet been incorporated into reference 8 .

Except for the fissile material contained in the entrained sludge solids, the amount of fissile material, primarily uranium and plutonium, to be transferred into the S-Area DWPF salt process areas is limited to that adsorbed on the monosodium titanate, which is added to the ITP process for strontium removal from the salt solution. Hobbs and Fleischman 7 indicated that the maximum loading of uranium plutonium on MST is governed by the following equations:

maximum U wt\% loading $=1.8-0.29(x)$

maximum Pu wt\% loading $=0.29-0.20(\mathbf{x})$ 
Nuclear Criticality Safety Analysis

Summary Report: The S-Area

Defense Waste Processing Facility
WSRC-RP-94-396

Rev. 0

Page 15 of 52

where $x$ is the MST concentration and ranges from 0.05 to 0.51 grams per liter.

Uranium competes with plutonium for the limited adsorption sites on MST. And, uranium solubility is about an order of magnitude greater than plutonium in waste solution. 22 It is expected that uranium is the major fissile material to be transferred from the salt solution to the S-Area DWPF process via adsorption on MST. And, indeed, the plutonium to uranium ratio is found to be less than 0.003 in the solids of Tank 48 precipitate slurry. 11

MST will be added during the first batch of a three batch ITP process cycle. And, sodium tetraphenylborate will be added in every batch. Approximately, 0.3 grams of MST per liter of decontaminated salt solution is currently planned.23,24 It is estimated that the maximum adsorbed uranium to enter the S-Area DWPF's salt process areas is less than 52 milligrams per liter of precipitate feed slurry, assuming that the precipitate slurry contains $3000 \mathrm{ppm}$ MST. Reference 8 indicates only $2225 \mathrm{ppm}$ of MST in the precipitate slurry feeds to the Precipitate Reactor. Likewise, the maximum adsorbed plutonium to be received in the salt process areas would be less than 6.9 milligrams per liter of precipitate feed slurry, also assuming $3000 \mathrm{ppm}$ MST in the precipitate slurry. A nominal batch cycle in the Late Wash Facility and Salt Processing Cell is about 11,355 liters. 18 Therefore, the maximum fissile material to be present in one salt processing batch cycle is 590 grams of uranium or 78 grams of plutonium.

Chandler 15 provided another estimate of the maximum equivalent uranium loading on MST to be $2.29 \%$ using the characteristics of process operation of the In-Tank Precipitation. That translates to less than 69 milligrams of equivalent uranium per liter of precipitate slurry to be transferred to the S-Area DWPF, or about 780 grams of equivalent uranium per salt process batch cycle. Equivalent uranium is defined as a combination of U-235 and Pu-239.15 Assuming 780 grams of equivalent uranium in one Precipitate Reactor batch and an abnormal evaporation of the Precipitate Reactor's content without the aqueous return from the condenser/decanter, the equivalent uranium concentration can only be increased to less than 0.2 grams per liter because the steam interlock will then be activated. The 
Nuclear Criticality Safety Analysis

Summary Report: The S-Area

Defense Waste Processing Facility
WSRC-RP-94-396

Rev. 0

Page 16 of 52

interlock turns off the steam to the heating coils, when the liquid level is below 4300 liters in the Precipitate Reactor and starts to uncover the steam coils.

It is also known that soluble uranium can form a complex with formate ions in high formic acid concentration and become insoluble.11,12 However, precipitation of uranium formate complex requires an almost complete evaporation of the aqeous content of the PR to below the steam coils, which is only possible if there are several process and equipment failures: (1) failures of the $P R$ condenser/decanter, which is impossible to persist without detection, and (2) malfunction of interlocks. Only, a maximum of 273 grams of soluble equivalent uranium may be precipitated as insoluble solids. Furthermore, there may be no more than one batch accumulation because of inoperable steam coils and, therefore, the PR due to tar accumulation when the steam coils become overheated.

It has also been established that if the fissile material is adsorbed on MST and there is an accumulation of solids in the salt process areas, the risk of nuclear criticality is negligible due to the ratio of titanium in MST to fissile material well above the safe ratio. $15,18,21$ In particular, assuming a bounding enrichment of $86 \%$ U-235 and an infinite system, at least thirty six (36) overbatching of MST mass additions are required before sufficient mass for criticality can accumulate. 15 Bess $^{21}$ recently documented criticality safety for 71 ITP batches. It means that all of the fissile material in the salt solution currently stored in the tank farm can accumulate in the $S$ Area DWPF salt process area, which is physically impossible, and still there is no nuclear criticality.

\section{Safe Weight Ratios for Sludge Process Streams}

Iron and manganese are the most abundant and effective neutron absorbers contained in the waste sludge. Clemmons and Goslen5-6 have established the minimum safe weight ratios for iron and manganese, in which a mixture of fissile materials and iron or manganese or a combination of iron and manganese cannot achieve criticality. The safe weight ratios were developed for an infinite system, and, therefore, are applicable for all geometries. Appendix B was derived from the report WSRC-TR-94-0191, "Estimated Sludge 
Nuclear Criticality Safety Analysis

Summary Report: The S-Area

Defense Waste Processing Facility
WSRC-RP-94-396

Rev. 0

Page 17 of 52

Inventory for Individual Tanks," by $\mathrm{H}$. Tran. 25 It shows a summary of sludge inventory including fissile materials, iron, and manganese, for individual waste tanks. The data came from accountability data reports, which are based on process control samples. They represent the current best estimates of SRS waste tank inventory.

Clemmons 17 assessed the criticality potential of individual waste tanks using safety parameters such as fissile material concentrations, fissile material areal densities, and ratio of manganese (Mn), iron (Fe), and U-238 to fissile material. It was shown that there is negligible risk of criticality in each waste tank. Since the S-Area DWPF process will be processing the same sludge waste material, it is now demonstrated that the DWPF is also operating with negligible risk of criticality using the same criteria and additional process knowledge.

For the S-Area DWPF process to be able to use some types of safe weight ratio arguments, it is important to locate the process chemistry which could change the effective ratios of neutron absorbers such as iron and manganese to fissile materials. Fissile material remains in the sludge solids through the entire DWPF process. 13,14 It was also discussed in the background information that iron remains in the sludge solids with the fissile material through the entire DWPF process. However, up to half of the manganese may become soluble during acid addition of the SRAT process cycle. Although the soluble manganese remains with the sludge slurry until it is finally converted into borosilicate waste glass in the Melter, soluble manganese is no longer considered to be an effective neutron absorber for the fissile materials in the sludge solids. The main reason is because the ratio of soluble $\mathrm{Mn}$ to the fissile material (or sludge solids) cannot be guaranteed under abnormal or upset conditions.

It is important to note that $50 \%$ represents the maximum amount of $\mathrm{Mn}$ to be dissolved into aqueous solution during the SRAT process cycle. The DWPF design basis asks for $40 \%$ of Mn to become soluble in order to mitigate the foaming problem in the Melter. 26 However, it was reported 27 that only about $45 \%$ of $\mathrm{Mn}$ in Tank 51 radioactive sludge became soluble when twice the required amount of acid was added. The $\mathrm{pH}$ of the waste sludge solution also seemed to be 
Nuclear Criticality Safety Analysis .

Summary Report: The S-Area

Defense Waste Processing Facility
WSRC-RP-94-396

Rev. 0

Page 18 of 52

buffered at a pH of 3.5. Iron was also observed to show no measurable solubility until the $\mathrm{pH}$ reached 3.8. The final $\mathrm{pH}$ of the SRAT cycle is aimed at 4 to 5 . If more than twice the amount of required acids were added to lower the $\mathrm{pH}$ below 3 , and, therefore, increasing the solubility of $\mathrm{Mn}$ and $\mathrm{Fe}$, the SRAT cycle will experience process difficulties, well before criticality safety becomes a concern.

Safety parameters relating to $\mathrm{Fe}$ and $\mathrm{Mn}$ as neutron poisons are expressed as simple weight ratios to fissile material. Throughout the S-Area DWPF chemical processes, iron essentially remains insoluble throughout normal operation and abnormal process upsets.13-14,26 The safe weight ratio of Mn to fissile material for the S-Area DWPF operation was increased to be twice the applicable safe weight ratio in the tank farm to take into account that up to 50 percent of manganese is expected to become soluble26-27 during acid treatment in the SRAT process. And, hence, about half of the $\mathrm{Mn}$ from the sludge feed will not contribute as neutron absorbers. It is important to note that the iron and manganese in the sludge solids are always associated with the insoluble fissile material due to the coprecipitation nature, as observed during Tank 51 campaign in the Savannah River Technology Center (SRTC) shielded cells.13-14 The minimum safe weight ratios have been determined for $\mathrm{Fe}$ and $\mathrm{Mn}$ as follows: $5-6,17$

For the tank farm

Fe:Pu-239:

Mn:Pu-239:

Fe:Mn:Pu-239:
160:1

$32: 1$

26.5:26.5:1

60:20:1

$80: 16: 1$

94.5:13.5:1

110:11:1
For DWPF

160:1

64:1

26.5:53:1

60:40:1

80:32:1

94.5:27:1

110:22:1 
Nuclear Criticality Safety Analysis

Summary Report: The S-Area

Defense Waste Processing Facility
WSRC-RP-94-396

Rev. 0

Page 19 of 52

\section{Criticality Safety Characteristics of Six Planned Major DWPF Sludge Batches}

In Table 1, the weight ratios of $\mathrm{Fe}$ and $\mathrm{Mn}$ to $\mathrm{Pu}-239$ and U-235 found in DWPF sludge batch 1 are compared to the calculated safe weight ratios 5-6,17. Two columns are used to represent the composition data of Batch 1. The first column represents experimental analysis of Tank 42 and Tank 51, which will be combined to form DWPF Batch 1 sludge feed.28,29 The second column uses the tank farm inventory. 17,25 Clemmons argued that although a documented fissile equivalency between U-235 and $\mathrm{Pu}$ 239 has not yet been published, the excessive margin of safety with these high ratios allows a simplistic conservative equivalency model to be used.16 Safe weight ratios of $\mathrm{Fe}$ and $\mathrm{Mn}$ to $\mathrm{Pu}-239$ are greater than the safe weight ratios of $\mathrm{Fe}$ and $\mathrm{Mn}$ to $\mathrm{U}-235^{5-6}$, respectively. It is reasonable to assume that the safe weight ratios of $\mathrm{Fe}$ and $\mathrm{Mn}$ to a combination of U-235 and $\mathrm{Pu}-239$, when they exist together, will be no greater than for an equal amount of $\mathrm{Pu}-239$. Using this argument, the existing $\mathrm{Fe}$ and $\mathrm{Mn}$ to equivalent $\mathrm{Pu}-239$ (U-235 $+\mathrm{Pu}$ 239) weight ratio is about 4 times greater than the infinitely safe ratio. Applying only $\mathrm{Fe}$ and $\mathrm{Mn}$ safe weight ratio is conservative since no credit is taken for several other diluents in the sludge feed that are significant neutron absorbers. $8,16,28-29$

Table 1. Comparisons of $\mathrm{Fe}$ and $\mathrm{Mn}$ to U-235 and Pu-239 Weight Ratios vs Calculated Safe Weight Ratios for DWPF Batch 1.

$\begin{array}{llll}\begin{array}{l}\text { Absorber } \\ \text { to Fissiles }\end{array} & \begin{array}{l}\text { Batch 128-29 } \\ \text { Wt Ratio }\end{array} & \begin{array}{l}\text { Batch 1 17,25 } \\ \text { Wt Ratio }\end{array} & \begin{array}{l}\text { Safe Wt. 5-6,16 } \\ \text { Ratios }\end{array} \\ \text { Fe/U-235 } & 1445: 1 & 1903: 1 & 77: 1 \\ \mathrm{Mn} / \mathrm{U}-235 & 192: 1 & 102: 1 & 60: 1 \\ \mathrm{Fe} / \mathrm{Pu}-239 & 3465: 1 & 2563: 1 & 160: 1 \\ \mathrm{Mn} / \mathrm{Pu}-239 & 460: 1 & 68: 1 & 64: 1 \\ \mathrm{Fe} / \mathrm{Eq} . \mathrm{Pu}-239^{*} & 1019: 1 & 1092: 1 & 160: 1 \\ \mathrm{Mn} / \mathrm{Eq} . \mathrm{Pu}-239^{*} & 135: 1 & 58: 1 & 64: 1\end{array}$

*All U-235 assumed to be $\mathrm{Pu}-239$ for comparison to safe $\mathrm{Pu}-239$ weight ratios. 
Nuclear Criticality Safety Analysis

Summary Report: The S-Area

Defense Waste Processing Facility
WSRC-RP-94-396

Rev. 0

Page 20 of 52

In Table 2, the weight ratios of $\mathrm{Fe}$ and $\mathrm{Mn}$ to equivalent $\mathrm{Pu}-239$ content in DWPF sludge batch 1 through 6 are compared to calculated safe weight ratios $5-6,17$. The tank composition data are estimated from (1) canyon discharge data 30 , (2) tank farm fresh waste receipt data 31 , and (3) tank farm waste transfer data32. They represent all of the SRS waste sludge to be eventually processed in the DWPF. The content of all of the sludge batches using the historical tank inventory data according to the current waste removal schedule 33 is summarized in appendix $\mathrm{C}$. The weight ratios of $\mathrm{Fe}, \mathrm{Mn}$, or a combination of $\mathrm{Fe}$ and $\mathrm{Mn}$ above minimum safe ratios exist for each DWPF major sludge batch. In particular, all of the DWPF sludge batches are safe based solely on the ratios of $\mathrm{Fe}$ to fissile material. Two batches, Batch 3 and 4, are safe solely based on the ratios of $\mathrm{Mn}$ to fissile material. Batch 1 sludge is also safe based on the ratio of Mn to fissile material using actual sample analysis. All of the sludge batches are safe based on the combined ratio of $\mathrm{Fe}$ and $\mathrm{Mn}$ to fissile material.

Table 2. Comparisons of $\mathrm{Fe}$ and $\mathrm{Mn}$ to Equivalent Pu-239* Weight Ratios vs Calculated Safe Weight Ratios for All of the Six Major DWPF Sludge Batches.

\begin{tabular}{|c|c|c|c|c|c|}
\hline $\begin{array}{l}\text { Major } \\
\text { Batches }\end{array}$ & $\begin{array}{l}\mathrm{Fe} \\
\text { Ratio }\end{array}$ & $\begin{array}{l}\text { Mn } \\
\text { Ratio }\end{array}$ & $\begin{array}{l}\text { Safe by } \\
\text { Fe only }\end{array}$ & $\begin{array}{l}\text { Safe by } \\
\text { Mn only }\end{array}$ & $\begin{array}{l}\text { Safe by } \\
\text { Fe \& Mn } \\
\text { Combined }\end{array}$ \\
\hline Batch 1 & 1092 & 58 & Yes & No & Yes \\
\hline Batch 2 & 365 & 57 & Yes & No & Yes \\
\hline Batch 3 & 374 & 104 & Yes & Yes & Yes \\
\hline Batch 4 & 549 & 87 & Yes & Yes & Yes \\
\hline Batch 5 & 205 & 26 & Yes & No & Yes \\
\hline Batch 6 & 1654 & 38 & Yes & No & Yes \\
\hline
\end{tabular}

*The equivalent Pu-239 is the sum of the U-233, U-235, Pu-239, and $\mathrm{Pu}-241$ content in the sludge.

These types of analyses for the planned six major sludge batches to be processed in the DWPF are also conservative since they also 
Nuclear Criticality Safety Analysis

Summary Report: The S-Area

Defense Waste Processing Facility
WSRC-RP-94-396

Rev. 0

Page 21 of 52

ignore the contribution of other neutron absorbers in the sludge feed such as $\mathrm{U}-238, \mathrm{Mg}, \mathrm{Ni}, \mathrm{Cr}$, and $\mathrm{Hg}$. $8,25,28,29,30$

Since DWPF criticality safety is based primarily on the characteristics of the feeds from the tank farm, it is now examined if there is a waste feed from the tank farm that violates these characteristics. Clemmons 17 showed that all of the current SRS waste inventory meet the basis of the tank farm criticality safety based either on the $\mathrm{Fe}$ or $\mathrm{Mn}$ to fissile material, or a combination of both. U-238 was also considered in the report 17 . There is insufficient $\mathrm{Fe}$ to meet the safe weight ratio for the following tanks: Tanks $6,30,36$, and 39 . There is insufficient $\mathrm{Mn}$ to meet the safe weight ratio for the following tanks: Tanks $5,6,8,11,18,21,22,28,32,33,34,35,36,39,40,41$, $42,43,47$, and 51 . Of these tanks, only Tanks 30,36 , and 39 , do not meet the criteria for the combination of $\mathrm{Fe}$ and $\mathrm{Mn}$ to fissile material weight ratio. Tanks 30 and 36 are concentrate receipt tanks which contain almost no sludge. Tank 39 is currently the HHW receipt tank for waste from H-canyon. The sludge volume of Tank 39 is about 110,000 gallons, which is not enough to make up a DWPF major batch, and it must be mixed and blended with other sludge tanks. Tank 39 is currently planned to be blended with other tanks to make up the fifth major sludge batch 33 , which is shown on Table 2 to be safe based on iron and a combination of iron and manganese to fissile material ratios.

Feed to the S-Area DWPF come from tanks that have no direct link to separation canyons. Therefore, except for Tank 39 sludge content, it is considered impossible for the S-Area DWPF to receive a feed which violates its criticality safety basis.

\section{Uranium Enrichment}

Another significant contributor to the criticality safe operation of the DWPF is the low uranium enrichment in the sludge feed slurries. Table 3 shows the overall enrichment of each major sludge batches as they are calculated using the above source of information. The subcritical mass limit for $1 \% \mathrm{U}-235$ as homogeneous oxide is greater than $7000 \mathrm{~kg}$ (TID-7016, Nuclear Safety Guide). At $0.95 \%$ U-235 enrichment, the subcritical mass limit for homogeneous oxide is essentially infinite. All of the planned sludge batches have a 
Nuclear Criticality Safety Analysis

Summary Report: The S-Area

Defense Waste Processing Facility
WSRC-RP-94-396

Rev. 0

Page 22 of 52

uranium enrichment of $0.76 \%$ or less. This further illustrates the wide margin of safety.

Table 3. Uranium Enrichment in Sludge Batches to Be Processed in the DWPF.

$\begin{array}{ll}\begin{array}{ll}\text { Major } \\ \text { Batches }\end{array} & \begin{array}{l}\text { Uraniu } \\ \text { Enrich }\end{array} \\ \text { Batch 1 } & 0.57 \% \\ \text { Batch 2 } & 0.54 \% \\ \text { Batch 3 } & 0.58 \% \\ \text { Batch 4 } & 0.70 \% \\ \text { Batch 5 } & 0.31 \% \\ \text { Batch 6 } & 0.75 \%\end{array}$

A major sludge batch contains a mixture of sludge blend from several waste tanks with a varying degree of uranium enrichment. Appendix $B$ indicates several tanks with high uranium enrichment, as high as $74 \%$ in Tank 15 . However, when Tank 15 will be mixed with Tanks 8 and 11 to form the major sludge Batch 2, the final uranium enrichment is about $0.55 \%$.

DWPF criticality safety arguments based on uranium enrichment was not pursued, however, because of the presence of plutonium in the sludge feeds. The ratios of U-238 to equivalent U-235, which includes plutonium, are less than the safe weight ratios of U-238 to fissile material.

\section{Safety Margins}

The safe weight ratios were determined conservatively and with excessive safety margins built-in. $5-6,17$

A major portion of the data in Appendix B, which was used to calculate the weight ratios of iron and manganese to fissile material, was derived from accountability data. 25 This portion of the data is the most accurate. The degree of uncertainty inherent in the accountability data comes from the limitations of analytical instrumentation and systematic variability with accountability practices dealing with special nuclear materials. The remaining data, 
Nuclear Criticality Safety Analysis

Summary Report: The S-Area

WSRC-RP-94-396

Defense Waste Processing Facility

Rev. 0

Page 23 of 52

in reference 25 , have another added degree of uncertainty since they are based on estimates using historical information contained in the Works Technical, Waste Management Monthly Reports, and accountability records.

An additional, though unquantified, safety margin is provided by the presence of other neutron absorbers, such as $\mathrm{U}-238, \mathrm{Mg}, \mathrm{Ni}, \mathrm{Cr}$, and $\mathrm{Hg}$. In particular, U-238 will always be present in significant quantities with fissile material throughout the DWPF process. It was shown in Table 3 that the uranium enrichment of the six planned major batches, all have enrichments of less than $0.76 \%$.

For the salt process areas, another undetermined safety margin is provided by the presence of a very effective neutron absorber, boron. Tetraphenylborate salt is the main reagent to be processed in the S-Area DWPF salt process areas, so it is always present. The concentration of boron in a nominal precipitate feed slurry is about 2.7 grams of $B$ per liter 8 .

\section{Criticality Analysis of Scenarios in the S-Area DWPF}

A group of people knowledgeable in the DWPF processes identified several upsets conditions which might lead to criticality problems. 34 These scenarios have been analyzed in two Nuclear Criticality Safety Evaluation reports. 18-19 It was shown that these upset conditions to be safe against a nuclear criticality with a safety factor of at least five for all materials expected in the first six sludge batches and their associated precipitate slurry feeds.

This section summarizes the two DWPF NCSEs 18-19 and also relevant nuclear criticality safety documents 5-6,15-17 from the tank farm dealing with the sludge and precipitate feeds, and discusses the scenarios outlined in reference 34 . In many cases, reference 18 used an enrichment to compute the equivalent U-235 content to demonstrate a margin of safety.

\section{Consideration of Abnormal and Upset Conditions}

Abnormal upsets have also been considered and some of the scenarios are discussed in sections specific to the Salt Processing Cell, 
Nuclear Criticality Safety Analysis

Summary Report: The S-Area

Defense Waste Processing Facility
WSRC-RP-94-396

Rev. 0

Page 24 of 52

the Chemical Processing Cell and the Melter. These upset scenarios, however, do not cause separation and accumulation of fissile materials from the bulk solids. Coprecipitation, during neutralization of acidic waste streams from separation processes entering the tank farm, tightly binds all of the chemical species in the sludge solids together.13,14,35,36 The coprecipitation solid structure may be homogeneous or heterogeneous, but a physical process such as settling cannot separate individual chemical species from the bulk solids. It requires a chemical reagent, like oxalic acid, which could selectively dissolve some of the most abundance species such as $\mathrm{Fe}$ and $\mathrm{Mn}$, but not fissile material, to effect the separation of fissile material from the bulk solids. The DWPF does not use any such chemical reagents in the process, nor store any in the DWPF process areas. Appendix A provides a detailed discussion of coprecipitation.

The DWPF process under the abnormal upset scenarios will remain critically safe since the $\mathrm{Fe}$ to fissile material safe weight ratios are not changed. The insoluble $\mathrm{Mn}$ to fissile material also does not change. The combined $\mathrm{Fe}$ and $\mathrm{Mn}$ ratios always stays above the minimum safe weight ratio. It is physically not possible for personnel error or equipment malfuntion to significantly alter these characteristics and impact criticality safety.

The Late Wash Facility and the Salt Processing Cell under the abnormal upset scenarios will also remain critically safe. A majority of fissile material remains adsorbed on MST, which is also a neutron absorber. The desorbed fissile material is soluble and its concentration is very dilute in the precipitate process streams. The high hydrogen-to-soluble-fissile ratio in the solution prevents a nuclear criticality.

\section{Late Wash Facility (LWF)}

Since the Late Wash Facility is similar to the design of the ITP process, the analysis of the Late Wash Facility follows closely the evaluation of the In-Tank Precipitation process. Chandler performed a bounding analysis for the ITP process and demonstrated that the potential for criticality due to adsorption of fissionable material by MST is incredible. 15 In particular, assuming a bounding enrichment of $86 \%$ U-235 and an infinite system, at least thirty six (36) 
Nuclear Criticality Safety Analysis

Summary Report: The S-Area

Defense Waste Processing Facility
WSRC-RP-94-396

Rev. 0

Page 25 of 52

overbatching of MST mass additions are required before sufficient mass for criticality can accumulate. 15 It means that there must be an accumulation of at least 37 ITP batches in the Late Wash Facility to cause a concern. Bess 21 recently documented criticality safety for 71 ITP batches.

It is deemed incredible to accumulate that many batches in the Late Wash Facility since that represents more material than all of the salt tanks currently contain. Besides, it is also deemed incredible to assume the MST mass representing thirty-seven (37) ITP batches, $37,000 \mathrm{~kg}$, could accumulate as a sphere at the optimum mixture density, greater than 1750 grams per liter, for criticality. 15

Williams on 18 also concluded that the Late Wash Facility does not pose a criticality safety concern, since there is no mechanism to separate fissile material from MST. Other neutron absorbers which are prevalent in the precipitate feed slurry also mitigate against a nuclear criticality.

Low Point Pump Pit Precipitate Tank (LPPPPT), Low Point Pump Pit Sludge Tank (LPPPST), Piping and Slurry Transfer Systems

There is no known physical or chemical mechanism for separation of fissile material from the bulk solids (precipitate and sludges) in these systems. Nuclear criticality is considered to be impossible in these systems and subsequent piping and slurry transfer systems. Therefore, they are inherently safe, with respect to nuclear criticality, because the bulk solids are inherently safe. Nuclear criticality is not an issue in the LPPPPT, the LPPPST or the piping and related transfer systems.

\section{Salt Process Cell (Precipitate Hydrolysis Process)}

The Precipitate Hydrolysis Process (PHP) is one of the places where chemical reactions and processes could potentially separate and accumulate fissile material in an unsafe configuration, with respect to nuclear criticality. The precipitate slurry fed to the Salt Process Cell poses no nuclear safety concern in the form delivered from the waste tanks15. As documented in reference 15, the maximum loading of 
Nuclear Criticality Safety Analysis

Summary Report: The S-Area

Defense Waste Processing Facility
WSRC-RP-94-396

Rev. 0

Page 26 of 52

uranium and plutonium on monosodium titanate (MST) is below the individual infinitely safe limits for plutonium and uranium.

The precipitate feed and subsequent process streams are always safe because:

(1) The abundance of titanium in MST as a neutron absorber.

(2) Desorbed fissile material is in a dilute aqueous solution, and, therefore, the high hydrogen-to-soluble-fissile ratio ensures that criticality due to soluble fissile is incredible.

(3) And, fissile material content in one precipitate batch is low enough such that a critical mass will not accumulate in tanks in the Salt Processing Cell.

Following is a discussion of nuclear safety concerns which were raised during early discussions on the DWPF criticality 34 . Williamson also discusses the issues raised in the mentioned report in a Nuclear Criticality and Safety Evaluation. $18 \mathrm{He}$ provided calculations to support the following arguments and to confirm that nuclear criticality is deemed incredible in the DWPF salt process areas.

Under normal operations, the contents of the Precipitate Reactor Feed Tank (PRFT), the Precipitate Reactor (PR), and the Precipitate Reactor Bottoms Tank (PRBT) are always safe, because of the inherent safety of the precipitate slurry. $15,18,21$

\section{Abnormal Process Upsets:}

The following process upsets assume that fissile material will be desorbed from MST as insoluble solids. Furthermore, these upsets were postulated 34 when it was not known that MST was an effective neutron absorber due to the nature of In-Tank Precipitation process.

\section{(a) Fouling}

In this scenario, the precipitate hydrolysis reactions have gone in unexpected directions, and significant fouling of the cooling coils in the PR by tars has occurred. The fissile material, 
Nuclear Criticality Safety Analysis

Summary Report: The S-Area

Defense Waste Processing Facility
WSRC-RP-94-396

Rev. 0

Page 27 of 52

mainly uranium and plutonium adsorbed on MST, is assumed to be distributed uniformly on the coils in the Precipitate Reactor (PR). Since this situation happened in the previously referenced HAN process where four precipitate hydrolysis batches were processed before fouling was discovered, the total amount of fissile material was assumed to be an accumulation of four batches. 37

As demonstrated by Chandler 15 , the titanium in MST will provide neutron poisoning to the adsorbed fissile material, and criticality is deemed incredible.

Fouling is not thought possible under the current late washing precipitate hydrolysis process based on process chemistry and pilot plant experience. This scenario was considered as the worst case scenario, as an upset or abnormal condition which could be monitored and detected by tracking of the heat transfer coefficient of the PR cooling coils 38 , but is no longer credible because of the change in the DWPF process.

Williamson 18 looked at a different fouling model. It was assumed that uranium and plutonium separated from MST and became insoluble. With a composition of 1250 grams of U-235 and 3125 grams of $\mathrm{Pu}-239$ deposited uniformly on the coils, the $\mathrm{K}_{\mathrm{eff}}$ was found to be 0.362 , using the one-dimensional cylindrical ANISN model with no account taken for axial leakage. It was concluded that the geometry is not favorable since the cooling coils of the PR are far from the center.

(b) Accumulation of Fissile Material due to Loss of Agitation.

In this scenario, fissile material was postulated to separate from MST and settle at the bottom of the PR or Precipitate Reactor Bottoms Tank (PRBT). Agitation was lost at the end of one batch, fissile material was assumed to settle uniformly to the bottom of these tanks with other solids, and another batch has been transferred into the vessel, causing accumulation of two batches of fissile material. This scenario is not credible, since loss of agitation is a process upset condition that would be detected before processing of more than. two batches is completed. It is believed that total amount of fissile material 
Nuclear Criticality Safety Analysis

Summary Report: The S-Area

Defense Waste Processing Facility
WSRC-RP-94-396

Rev. 0

Page 28 of 52

in two PR batches (and also two PRBT batches), will not cause a nuclear safety concern.

This scenario assumes incorrectly that fissile material separates from MST as an insoluble solid. Fissile material adsorbed on MST during the In-Tank Precipitation come from soluble uranium and plutonium in the salt solution. It is expected that if fissile material is separated from MST, it will become soluble again. There is experimental evidence that the $35 \%$ of depleted uranium separated from MST during formic acid boiling experiments is soluble. 11

Even in the hypothetical worst case situation, when "fissile material does desorb from MST as solids, and settles at the bottom of the PR, it has been established that criticality is incredible. 18

(c) Accumulation of Fissile Material in SPC Sump.

Process leaks, spills, and floor flushes in the Salt Process Cell (SPC) are collected in sump collection systems. Both aqueous and organic solutions will be collected. The remote sump pump ordinarily discharges to the $P R$ to prevent the spread of organics outside the SPC. A direct jumper route from the sump pump to the Formic Acid Waste Header and the Hot Decontaminated Waste Header is also provided for future use if necessary. This direct jumper will discharge the sump into the Recycle Collection Tank (RCT). In the worst case scenario the entire contents of both the PR and the PRFT are discharged onto the floor and collected in the sump.

Again, it has been demonstrated by Chandler 15 and Bess 21 that adsorbed fissile material on MST cannot become critical. It will require at least 37 batches of ITP operation to accumulate enough material to cause a concern. That is longer than the entire life of the DWPF process.

(d) Accumulation in Condenser/Decanter

During the steam distillation portion of the precipitate hydrolysis reaction cycle, an equivalent of 4 lbs of water per 
Nuclear Criticality Safety Analysis

Summary Report: The S-Area

Defense Waste Processing Facility
WSRC-RP-94-396

Rev. 0

Page 29 of 52

pound of insoluble solids fed to the reactor is evaporated into the Precipitate Reactor Condenser Decanter (PRCD). Aqueous phase flows from the decanter (PRCD) back to the PR; and organic phase overflows to the Organic Evaporator (OE).

Accumulation of fissile material in the PRCD was thought possible due to steam stripping and entrainment. This concern was discussed but no nuclear safety concern was identified. The entrained solids will contain MST with adsorbed fissile material, which will provide a defense against criticality. 15 Accumulation of fissile material in the PRCD is also thought not possible for more than 1 batch. At the end of the PR cycle, all of the material would be returned to the PR.

(e) Accumulation in the Organic Evaporator

Organic materials collected in the $O E$ are recirculated to the PRCD to remove heavy organics collected during steam distillation. After precipitate reactor operation is completed, the organic-water mixture is mixed with high speed agitation to extract radionuclides, primarily $\mathrm{Cs}-137$, from the organics prior to evaporation. Eventually, the aqueous phase will be returned to the PR at the end of the OE cycle via the PRCD.

Fissile material may reach the $\mathrm{OE}$, but it would come from entrained insoluble solids. However, fissile material will eventually end up back in the PR. It has been demonstrated that adsorbed fissile material on MST cannot go critical due to neutron absorption provided by titanium in the MST.15,18,21

(f) Decontamination Route.

This is not a concern since material in the SPC sump is expected to be transferred to the $\mathrm{PR}$ for processing. In the case where the sump content is routed to the RCT, the material is inherently safe, as demonstrated by Chandler 15 , Williamson 18 , and Bess $^{21}$, throughout the DWPF process. 
Nuclear Criticality Safety Analysis

Summary Report: The S-Area

Defense Waste Processing Facility

WSRC-RP-94-396

Rev. 0

Page 30 of 52

\section{Chemical Process Cell}

The Sludge Receipt and Adjustment Tank is the only place in the DWPF process where there is a change in the weight ratio of Mn to fissile material due to the chemistry of the process. During the acid addition cycle, up to $50 \%$ of the manganese will be dissolved into solution from the bulk solids, away from the fissile material. The iron remains essentially unchanged through out the SRAT processing cycle. Batch 1 operation will be discussed first, followed by a discussion of the subsequent batches.

A worst case scenario in the Slurry Mix Evaporator (SME) is already documented.39 It involved the volume reduction of the "sludge slurry without frit to below the heating coils of the SME by evaporation. The $K_{\text {eff }}$ was found to be less than 0.3 during the investigation. Following are nuclear criticality concerns in the Chemical Process Cell, in particular, the SRAT vessel, which have been evaluated for DWPF Batch 1 composition. 18 The conclusions were also extended to other planned major sludge batches. 18

(1) Normal Operation:

Processing streams representing the start of the SRAT reaction cycle (the sludge feed) and the end of the SRAT cycle (the SRAT to SME transfer stream) are shown to be inherently safe with respect to nuclear criticality during normal operating conditions. 18 Reference 18 indicated that criticality safety is guaranteed if the uranium enrichment remains below 5\%. Since uranium enrichment in all of the major sludge batches will be less than $1 \%$, it can be considered that the DWPF operation is safe by a margin of 5 .

The fissile content in the SRAT process is sufficiently dilute so that criticality is not a problem during normal operation, in which the sludge solids are completely suspended in the aqueous solution. This can also be interpreted that if the solids are completely dissolved in aqueous solution, nuclear criticality is incredible. 
Nuclear Criticality Safety Analysis

Summary Report: The S-Area

Defense Waste Processing Facility
WSRC-RP-94-396

Rev. 0

Page 31 of 52

(2) Abnormal Process Upsets:

(a) There was a concern that plutonium oxide may be dissolved in the mercury in the mercury trap in the SRAT.40 It was postulated that plutonium could accumulate over time in the mercury trap, and cause a nuclear safety concern. The distribution of plutonium was experimentally determined between the aqueous sludge slurry phase and the mercury phase using simulated sludge doped with a known amount of plutonium and Tank 42 sludge. It was found that the plutonium dissolved in the mercury in the mercury trap during the SRAT reaction cycle was less than $6 x^{*} 10^{-6}$ grams of plutonium per gram of mercury, which amounts to about 2 grams of $\mathrm{Pu}-239.41$ This concentration is too low to accumulate enough plutonium in the mercury trap to cause a concern.

(b) The abnormal process upset which blinds the coils with sludge solids is a scenario that could cause changes in the $\mathrm{Fe}$ and $\mathrm{Mn}$ to fissile material safe weight ratios. There is a concern relating to fouling of the SRAT vessel after the process upset and subsequent clean-up procedure. However, there is no reference cleaning procedure and, therefore, a nuclear criticality safety evaluation of the clean-up operation of the SRAT has not been performed. If the SRAT internals are fouled by the sludge solids and a clean-up procedure has to be performed to restore the SRAT to operational status, the clean-up procedure is viewed as an abnormal operation which is not covered under this assessment. Once this process is defined, its safety (in terms of criticality) will be evaluated.

In general, if a cleaning procedure does separate the uranium from other solids, nuclear criticality safety would not be compromised if uranium enrichment remains below $15 \%\left(\mathrm{~K}_{\text {eff }}=0.929\right.$ for Batch 1 sludge composition $) .18$ 
Nuclear Criticality Safety Analysis

Summary Report: The S-Area

Defense Waste Processing Facility

\section{Melter}

The nuclear criticality concerns in the Melter have been discussed before. 42 Additional issues were, however, asked to be considered.

\section{(1) Normal Operation:}

The waste sludge is vitrified in the melter in the Melt Cell. A nuclear criticality safety evaluation 19 was performed on the melter using Batch 1 composition. It was concluded that the system remains subcritical for an infinite system under normal operations. The major contributing factors to the criticality safety are (1) low uranium enrichment (less than $1 \% \mathrm{U}-235$ in the Batch 1 sludge), (2) lithium, and (3) high levels of boron.

The same conclusion for the processing of other sludge batches can also be reached by using only the $\mathrm{Fe}$ and $\mathrm{Mn}$ weight ratios to fissile material.

\section{(2) Abnormal Process Upsets:}

It was shown in the NCSE 19 that any potential mechanism that could leach out boron, would have to remove $98 \%$ of the boron to cause a concern. However, there is no separation mechanism of plutonium and uranium accumulation identified in the melter.

Following are discussions of two additional issues related to the nuclear safety of the melter.

(a) There has been a concern about plutonium accumulation in the melter which could be a potential source of a nuclear criticality incident during the melter's 2-year life. ${ }^{43}$ Experimental data indicates that the plutonium oxide is soluble in borosilicate glass at the ratio of $6 \times 10^{-3} \mathrm{~g} \mathrm{PuO}_{2}$ per gram of frit. 44 Using optical and Mossbauer spectra, Karraker 44 inferred that from the valence state, $\mathrm{Pu}$ is a part of the borosilicate network. Plodinec and Wiley indicated that as much as $7 \%$ plutonium oxide is soluble in borosilicate glass. 45 The plutonium oxide to frit ratio during Batch 1 operation in $S$-area will be about $2 \mathrm{x}$ $10^{-5} \mathrm{~g} \mathrm{PuO}_{2}$ per gram of frit. 8 Thus, the amount of plutonium 
Nuclear Criticality Safety Analysis

Summary Report: The S-Area

Defense Waste Processing Facility
WSRC-RP-94-396

Rev. 0

Page 33 of 52

in the melter will be low compared to the amount of plutonium which, based on experiments, can be easily accommodated in solid solution in the borosilicate glass matrix. Under normal melter operation, no plutonium separation and, hence, no accumulation in the melter is possible. There is also no known abnormal process upset which might separate the plutonium from the borosilicate glass matrix.

(b) In an early nuclear criticality safety evaluation 42 , an abnormal upset scenario was considered where a SME batch was added to the melter without the frit. In this case, the sludge slurry composition is essentially the same at the end of the SRAT cycle, and in the SME, Melter Feed Tank (MFT), and Melter. Nuclear criticality safety issues addressed previously in the Chemical Processing Cell are also relevant. 18 It was determined that it was safe because the Kinfinite was very low, 0.063 . 42 The concern was raised on what would happen when the fissile material is drained into the dump canister. Since $\mathrm{K}_{\text {infinite }}$ is valid for any geometry, nuclear criticality in the dump canister or in the drain valve is impossible under this scenario.

In a similar fashion, Williamson 19 also showed that the infinite multiplication factor for the Batch 1 melter feed with $1 \%$ water is 0.853 , assuming no boron or lithium and a U-235 content of 40 weight percent of the total uranium. Nuclear criticality is, therefore, considered impossible if the Melter feed is mistakenly added to the melter without glass frit.

\section{Process Vent and Off-Gas Systems}

There have been situations, both on-site and off-site, indicating that solids accumulation in the vent systems can be a significant nuclear safety concern. However, this is not true for the DWPF's process vent and off-gas system.

In the DWPF vent and off-gas systems, entrainment is the only mechanism for fissile material to accumulate. Since there will be no preferential separation of fissile material from the (entrained) bulk solids, nuclear criticality is not possible as shown in the DWPF sludge 
Nuclear Criticality Safety Analysis

Summary Report: The S-Area

Defense Waste Processing Facility
WSRC-RP-94-396

Rev. 0

Page 34 of 52

feed section. There will always be abundant amounts of $\mathrm{Fe}$ and $\mathrm{Mn}$ in the sludge to prevent nuclear criticality in any entrained solids.

Solids accumulation in the melter's off-gas system is likely to depend more on the volatile melter feed components. However, boron, which is added in large quantities as borosilicate glass frit and is a major constituent of the PHA, is considerably more volatile than $U$ and $\mathrm{Pu}$ and would accumulate in larger amount in the melter off-gas systems, additionally providing neutron absorption for the fissile material. The accumulation of fissiles in the melter's off-gas system in sufficient concentration to cause a concern is not credible.

\section{Mercury Purification}

Water and mercury distilled from the SRAT during boil-up will be collected continuously in the Mercury Water Wash Tank (MWTT). Condensate will be transferred to the SRAT and SMECT. Undistilled mercury and amalgamated metals which have accumulated in the SRAT sump will be transferred to the MWTT.

Mercury will be washed with water to remove entrained sludge, formic acid and other contaminants. Washed mercury is transferred to the Mercury Purification Cell and washed with nitric acid to remove water insoluble salts. A final scrub is provided by passing mercury countercurrent with nitric acid through packed columns and water scrub streams. After analyzing to confirm the radioactivity is below detectable limits, the washed mercury is vacuum distilled and stored before shipment to 200-H Area.

Since plutonium does not accumulate to any significant levels in the mercury trap of the SRAT vessel, there is no concern in the mercury purification system.

\section{Recycle Collection Tank (RCT)}

All radioactive waste solution generated in the S-Area DWPF will be neutralized and transferred to the waste farm through the Recycle Collection Tank. Contents of the RCT will be chemically adjusted to yield a solution of $1 \mathrm{M}$ free hydroxide and $0.04 \mathrm{M}$ nitrite 39 . These 
Nuclear Criticality Safety Analysis

Summary Report: The S-Area

Defense Waste Processing Facility
WSRC-RP-94-396

Rev. 0

Page 35 of 52

levels of corrosion inhibitors will ensure adequate corrosion protection for the waste receipt tank in the Interim Waste Storage Facility.

In the RCT, solids precipitate when the contents are neutralized. Uranium and plutonium are sparingly soluble in alkaline solution and will precipitate during the treatment. $22 \mathrm{Fe}$ and $\mathrm{Mn}$ compounds are also known to be very insoluble in alkaline solution and will also precipitate.46-48 Since this is essentially the same process by which the waste is generated, coprecipitation of $\mathrm{Fe}, \mathrm{Mn}, \mathrm{U}$, and $\mathrm{Pu}$ will follow. The RCT is a stirred tank, and will mix the precipitated solids. The $\mathrm{Fe}$ and $\mathrm{Mn}$ to fissile material weight ratios will be similar to the ratios in the sludge feed slurry, which is safe with respect to nuclear criticality.

\section{Decontamination Waste Treatment Tank}

This concern is also related to the process vent and off-gas systems. HEME and HEPA filters are the active filter elements used in the process vent and off-gas systems. These spent filter elements will be processed in the Decontamination Waste Treatment Tank (DWTT). Since the HEME and HEPA are both composed of fiberglass, they can be reduced to a slurry in a sodium hydroxide solution.

There is a concern that solids accumulation in these spent filter elements could lead to separation and accumulation of fissile material in the DWTT after the filter element is dissolved. However, there is no mechanism to accumulate significant fissile material in the filter element other than entrainment, and also no mechanism which will preferentially separate the other solids from fissile material. Nuclear criticality is not possible because the $\mathrm{Mn}$ and $\mathrm{Fe}$ to fissile material weight ratios are always in excess of the calculated safe weight ratios. There will always be abundant amounts of $\mathrm{Fe}$ and $\mathrm{Mn}$ in the sludge to prevent nuclear criticality.

\section{Criticality Incident Scenarios and Alarm System}

An analysis of criticality incident scenarios and their impact was not addressed in this report. The above complete assessment of the DWPF operation indicates that the DWPF will be operating under a negligible risk of nuclear criticality. Applicable Nuclear Criticality 
Nuclear Criticality Safety Analysis

Summary Report: The S-Area

Defense Waste Processing Facility
WSRC-RP-94-396

Rev. 0

Page 36 of 52

Safety Evaluations (NCSE) ${ }^{18-19}$ have shown that criticality incident scenarios are not credible.

Since there are neither nuclear criticality controls nor limits during the DWPF operation, no criticality alarm system in the S-Area DWPF is needed.

\section{Conclusions}

Following are characteristics of the DWPF process which ensures operation with a negligible risk of nuclear criticality during normal operation and abnormal operation or process upset conditions.

1. The DWPF sludge feeds from the current tank farm inventory contain an abundance of neutron absorbers, primarily iron and manganese, which prevent nuclear criticality.

2. The DWPF process chemistry does not cause separation of fissile material from the sludge solids, which contain neutron absorbers.

3. As a special case which only applies in the Late Wash Facility and the Salt Processing Cell, adsorbed fissile material on monosodium titanate in the precipitate process streams are critically safe because:

a. Monosodium titanate (MST) is also an effective neutron absorber.

b. In case of fissile material desorbed from MST during the acid hydrolysis reaction, the high hydrogen to fissile ratio prevents the soluble fissile material from undergoing criticality.

c. Furthermore, the fissile material content in one precipitate batch is low enough that a critical mass does not accumulate in tanks in the Late Wash Facility and Salt Processing Cell. 
These conclusions were reached without consideration of other neutron diluents or absorbers which are prevalent throughout the entire DWPF process. In the special case of the Late Wash Facility and the Salt Processing Cell, boron, which is a very effective neutron absorber, is one of the main reagents in the salt processing chemistry and is present in all precipitate process streams. In the sludge process streams, there are $\mathrm{Al}, \mathrm{Ni}, \mathrm{Hg}, \mathrm{U}-238, \mathrm{Mg}$, and $\mathrm{Cr}$, which are also neutron diluents or absorbers in sludge solids with the fissile material. Of special interest is the abundance of $\mathrm{U}-238$ as the uranium enrichments of the six planned major sludge batches are all less than $1 \%$.

\section{Recommended Actions}

Isotopic analysis of fissionable material in the slurry feeds are recommended to be performed by the Savannah River Technology Center (SRTC) prior to processing each major sludge batch in the SArea DWPF process as a confirmation/verification of the safety basis established by this report.

For each sludge batch to be processed in the S-Area DWPF process, sludge samples will be transferred to the Shielded Cells in SRTC for process demonstration of production of acceptable waste glass. It is also recommended that SRTC provide a confirmation/verification of the safety basis based on results of these process demonstrations.

A summary statement based on results of (1) feed characterization, and (2) process demonstration, as recommended above, should be included in the same transmittal from SRTC to DWPF concerning the acceptability of the waste glass.

The purpose of the confirmation/verification effort to be carried out prior to actual processing of each major sludge batch is to ensure that any future changes in the tank farm's waste removal schedule or the DWPF process chemistry will not invalidate the safety basis of this report. 
Nuclear Criticality Safety Analysis

Summary Report: The S-Area

WSRC-RP-94-396

Defense Waste Processing Facility

Rev. 0

Page 38 of 52

\section{Appendix A}

\section{Characteristics of the S-Area DWPF Waste Feeds and Process Chemistry}

\section{Waste Characteristics}

All liquid wastes generated in the separation facilities are acidic. Sodium hydroxide is added to neutralize the separation process streams to prevent corrosion of the waste tanks, since SRS waste tanks are made of carbon steel. The $\mathrm{pH}$ of the liquid wastes from the separation process streams is raised from less than 2 to about 11 during the basic treatment prior to discharge into the waste tanks. Many components of waste become insoluble and form a precipitate, which is called "sludge".

The composition of the sludge is of significant interest. The solubilities of the fissile radionuclides encountered in the separation processes are very low in basic solutions, and therefore, most of these materials are deposited in the sludge. Furthermore, the presence of other elements in the waste sludge, which would act as diluents or neutron absorbers, significantly affects the criticality safety characteristics of the sludge. The separation processes use reagents which are also highly insoluble in basic solution, and therefore, have been precipitated into the sludge solids during the basic treatment of liquid wastes from the separation facilities. Cavin 30 quantifies the relative amount of fissile materials and potential neutron poisons in the sludge solids.

\section{Salt Solution}

A number of species in the waste are soluble in caustic solutions and thus are transferred to the waste tanks as soluble salts. The liquid solutions are called supernates or salt solutions. The salt solution is then decanted from the sludge solids, and treated in the In-Tank Precipitation (ITP) process, before it is transferred to the DWPF. The process objectives of ITP are to (1) segregate radioactive cesium and strontium into a high activity, low volume precipitate feed stream to DWPF, and (2) produce a low activity feed stream to Saltstone facility. 
Nuclear Criticality Safety Analysis

Summary Report: The S-Area

Defense Waste Processing Facility
WSRC-RP-94-396

Rev. 0

Page 39 of 52

In the ITP process, sodium tetraphenylborate is added to the salt solution to precipitate the radioactive soluble $\mathrm{Cs}-137$, as cesium tetraphenylborates $\mathrm{CsB}\left(\mathrm{C}_{6} \mathrm{H}_{5}\right) 4$. Since potassium tetraphenylborates $\mathrm{KB}\left(\mathrm{C}_{6} \mathrm{H}_{5}\right) 4$ are also insoluble in an aqueous solution, they are also precipitated along with the cesium tetraphenylborates. Monosodium titanate (MST) $\mathrm{Ti}_{2} \mathrm{O}_{5} \mathrm{H}$ is added to the precipitate slurry to adsorb soluble radioactive $\mathrm{Sr}$. Soluble plutonium and uranium are also found to be adsorbed on the MST in the ITP process. ${ }^{7}$

\section{Salt Processing Cell}

The waste precipitate slurry from the tank farm is washed in the Late Wash Facility to reduce the concentration of nitrites, and other non-radioactive soluble salts. The washed precipitate slurry feed is then treated in the Precipitate Reactor (PR) in two processing steps: (1) acid hydrolysis of tetraphenylborate salts in the precipitate slurry, and (2) benzene distillation. The purposes of the PR processing cycles are to (1) destroy tetraphenylborate salts and recover soluble cesium, (2) destroy nitrite, (3) separate and recover benzene and other organics, and (4) provide formic acid (or formate) for subsequent SRAT and Melter operations. The significant effect of the PR cycle is the acidifying of the precipitate slurry to a $\mathrm{pH}$ of about 2 .

Following are major chemical reactions in the PR:

Tetraphenylborate hydrolysis

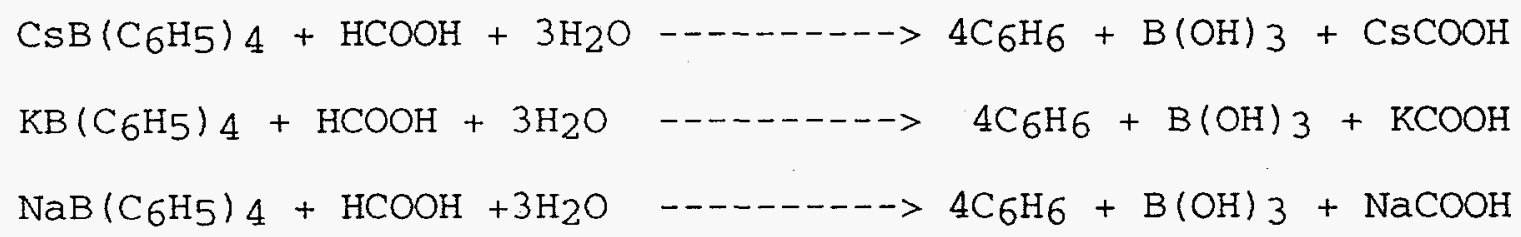

Nitrite destruction

$\mathrm{NaNO}_{2}+\mathrm{HCOOH}+\ldots+-.->\mathrm{HNO} 2+\mathrm{NaCOOH}$

Diphenylmercury acid cleavage

$\mathrm{Hg}\left(\mathrm{C}_{6} \mathrm{H}_{5}\right)_{2}+\mathrm{HCOOH}+-\cdots-\cdots>\mathrm{CO}_{2}+2 \mathrm{C}_{6} \mathrm{H}_{6}+\mathrm{Hg}$ 
Nuclear Criticality Safety Analysis

Summary Report: The S-Area

Defense Waste Processing Facility

WSRC-RP-94-396

Rev. 0

Page 40 of 52

The reaction product of the $P R$ is called the Precipitate Hydrolysis Aqueous product (PHA). The PHA is transferred to the Precipitate Reactor Bottoms Tank (PRBT) for storage prior to transfer into the SRAT.

The fissionable material in the Late Wash Facility and the Salt Processing Cell comes from two different sources in the precipitate slurry: (1) adsorbed uranium and plutonium on monosodium titanate and (2) fissionable material in entrained sludge solids. Although no reaction in the Salt Processing Cell involves separating fissionable material, fissionable material does desorb from monosodium titanate during the benzene distillation and subsequent total reflux cycle.

\section{Sludge}

This section will discuss aspects of the SRS tank farm chemistry which significantly impact the nuclear criticality safety characteristics of the S-Area DWPF process. Of primary interests are the abundance of two neutron absorbers, iron and manganese, and the coprecipitation nature of the sludge solids. Besides iron and manganese, the sludge solids also contain other potential diluents and neutron absorbers, such as $\mathrm{Al}, \mathrm{Ni}, \mathrm{Hg}, \mathrm{U}-238, \mathrm{Mg}$, and $\mathrm{Cr}$. However, iron and manganese will be emphasized throughout this report due to their roles in the criticality safety characteristics of the waste sludge.

The most abundant components of waste sludge are iron complexes, primarily $\mathrm{Fe}(\mathrm{OH}) 3$ which are formed from the neutralization of acidic separation waste streams containing ferrous sulfamate, $\mathrm{Fe}\left(\mathrm{SO}_{3} \mathrm{NH}_{2}\right)_{2}$. Ferrous sulfamate is used in both $\mathrm{F}$ and $\mathrm{H}$-Canyon separation areas as a reductant in the solvent extraction processes. The other major source of iron in Low Heat Waste (LHW) was ferrous sulfamate used in the Frames ( $\mathrm{Pu} / \mathrm{Np}$ recovery) process. Cavin provides an estimate of the iron amount in the waste tanks by analyzing the applicable separation process flowsheets. 30

The manganese oxide, $\mathrm{MnO}_{2}$, which went to the High Activity Waste (HAW) system from the Purex process was from the Head End Process. $\mathrm{MnO}_{2}$ precipitate was used to adsorb certain fission products from Head End process solutions. The precipitate was then 
Nuclear Criticality Safety Analysis

Summary Report: The S-Area

Defense Waste Processing Facility
WSRC-RP-94-396

Rev. 0

Page 41 of 52

removed by centrifugation and disposed of through the HAW neutralization tank. Most of the manganese discarded from the $\mathrm{H}$ Canyon separation process also came from the Head End process. The other major source of manganese is from the dissolution of stainless steel in the H-Canyon electrolytic dissolver. Potassium permanganate, $\mathrm{KMnO}_{4}$, from equipment decontamination in $\mathrm{F}$ Canyon is disposed through the Low Activity Waste (LAW) system. This manganese is discarded primarily as $\mathrm{MnO}_{2}$, after evaporation and neutralization treatment. An estimate of the discharge amounts of $\mathrm{Mn}$ to the tank farm is also provided by Cavin. 30

Before the sludge is fed to the S-Area DWPF process, it is treated in the Extended Sludge Processing (ESP) facility in the tank farm: The ESP is just a simple dilution process. The major process objectives are to (1) reduce total alkali content in the sludge, and to (2) reduce aluminum concentration, if needed. This processing step is required to blend the sludges from different waste tanks and to prepare the sludge feed for the DWPF process.

During neutralization treatment of the acidic separation process streams prior to discharge into the SRS tank farm, many components of the waste, including fissile materials and chemical species, become insoluble and form the sludge solids. It is believed that the sludge solids are formed by the coprecipitation phenomena. The following discussion attempts to illustrate the coprecipitation nature of the sludge solids.

Coprecipitation phenomena is defined as the contamination of a precipitate by substances that are normally soluble under the conditions of the precipitations. 49 There are three classes of coprecipitation phenomena: (1) adsorption at the surface of particles exposed to the solution, (2) occlusion by incorporation of foreign ions (and solvents) during the formation of the precipitate, and (3) chemical-compound formation. Occlusion by incorporation of foreign ions (and solvents) during the formation of the precipitate is the most common type of coprecipitation phenomena, and is suspected to be the coprecipitation mechanism during neutralization of the acidic separation process streams by the addition of caustic solution.

In going from an acidic solution, with $\mathrm{pH}$ of 2 or less, to a caustic solution, with $\mathrm{pH}$ of 10 or more, $\mathrm{Pu}$ is the least soluble species, 
Nuclear Criticality Safety Analysis

Summary Report: The S-Area

Defense Waste Processing Facility
WSRC-RP-94-396

Rev. 0

Page 42 of 52

followed by $U$, then iron, and manganese. During the neutralization of acidic separation area process stream discharges to the tank farm, $\mathrm{Pu}$ and $\mathrm{U}$ precipitate first. However, due to the abundance of iron and manganese in the waste solutions, these ions are incorporated into the crystal lattice of the fissile material precipitates in the form of a mixed crystal solid solution, for example: $\mathrm{UO}_{2}+\mathrm{PuO}_{2}+\mathrm{MnO}_{2}+\mathrm{Fe}(\mathrm{OH})_{3}$.

It is also likely that the sludge solids are formed by a flocculation mechanism. During the rapid increase of $\mathrm{pH}$ during the neutralization treatment, fissile materials tend to form solid crystals first because of their lesser degrees of solubility in an alkaline solution. Flocculation happens as crystallization of different chemical species happening at the same time, and causes crossbridging of different crystal structures. The solid structure is composed of heterogeneous crystal structures rather than homogeneous solid solution as in cases of true coprecipitation.

There is no direct evidence of coprecipitation phenomena, but it has been used indirectly by Clemmons 35 to explain why separation of fissile materials from the sludge solids has not been found in the tank farm. Clemmons 35 examined the $\mathrm{U}, \mathrm{Pu}, \mathrm{Fe}$ and $\mathrm{Mn}$ content in Tank 42 during the 1982-83 Extended Sludge Processing (ESP) demonstration. It was found that $U$ was removed from the sludge during the $\mathrm{Al}$ dissolution. For the three wash decants after $\mathrm{Al}$ dissolution, it appeared that $U$ was no longer being dissolved, but rather being diluted. The data also showed that $\mathrm{Pu}$ was not removed from the sludge solids as the concentration of soluble $\mathrm{Pu}$ decreased according to dilution mechanism. The amount of $\mathrm{Fe}$ and $\mathrm{Mn}$ in the sludge solids has not significantly changed during the ESP demonstration.

Hay and Bibler ${ }^{36}$ also observed essentially the same behavior of $U$, $\mathrm{Pu}, \mathrm{Fe}$, and $\mathrm{Mn}$ in the ESP experiments in the shielded cells involving Tank 42 and 51 sludges. It has been attributed that the coprecipitation sludge solid structure is responsible for the behavior of $\mathrm{U}, \mathrm{Pu}, \mathrm{Fe}$, and $\mathrm{Mn}$ during ESP. During Al dissolution, a substantial amount of $\mathrm{Al}$ is dissolved, which then releases the fissile material occluded in the solid structures associated with Al. Since $U$ is much more abundant, 100 to 1000 times more than $\mathrm{Pu}$, it is more readily detected and measured than $\mathrm{Pu}$. However, the $U$ concentration is 
only few percent based on the solids in a Purex sludge, and is much less in a HM sludge. During subsequent washing, no chemical species are dissolved, and, therefore, no increase of soluble $U$ and $\mathrm{Pu}$ concentration is observed, as it is suspected that the remaining $U$ and $\mathrm{Pu}$ are locked in the sludge solid structures.

\section{Chemical Process Cell}

The washed waste sludge slurry from the tank farm is treated in preparation of the melter feed in the Sludge Receipt and Adjustment Tank (SRAT) in three processing steps: (1) addition of nitric acid, and (2) addition of the Precipitate Hydrolysis Aqueous product (PHA) from Salt Processing Cell (SPC), and (3) steam stripping of mercury. All of the SRAT operation happens at 93 to $100^{\circ} \mathrm{C}$ temperature." The purposes of the SRAT processing cycles are to (1) reduce mercury to elemental state for subsequent recovery by steam stripping, (2) partially reduce $\mathrm{MnO}_{2}$ to $\mathrm{Mn}$ (II) ion to mitigate foaming in the melter, (3) destroy nitrite, and (4) neutralize or acidify the sludge slurry for rheology purposes. The significant effect of the SRAT cycle is the acidifying of the sludge slurry from $\mathrm{pH}$ of 11 or above to a $\mathrm{pH}$ of about 4 to 5 .

Following are major chemical reactions in the SRAT. 26

Acid-Base Neutralization Reactions:

\begin{tabular}{|c|c|c|c|c|}
\hline $\mathrm{Na}^{+} \mathrm{OH}^{-}$ & + & $\mathrm{H}^{+}$ & $---------->$ & $\mathrm{Na}^{+}+\mathrm{H}_{2} \mathrm{O}$ \\
\hline $\mathrm{K}^{+} \mathrm{OH}^{-}$ & + & $\mathrm{H}^{+}$ & $---------->$ & $\mathrm{K}^{+}+\mathrm{H}_{2} \mathrm{O}$ \\
\hline $\mathrm{Ca}(\mathrm{OH}) 2$ & + & $\mathrm{H}^{+}$ & $---------->$ & $\mathrm{Ca}^{++}+\mathrm{H}_{2} \mathrm{O}$ \\
\hline $\mathrm{Ba}(\mathrm{OH}) 2$ & + & $\mathrm{H}^{+}$ & $---------->$ & $\mathrm{Ba}^{++}+\mathrm{H}_{2} \mathrm{O}$ \\
\hline $\mathrm{Mg}(\mathrm{OH}) 2$ & + & $\mathrm{H}^{+}$ & $---------->$ & $\mathrm{Mg}^{++}+\mathrm{H}_{2} \mathrm{O}$ \\
\hline $\mathrm{CaCO}_{3}$ & + & $\mathrm{H}^{+}$ & $----------->$ & $\mathrm{Ca}^{++}+\mathrm{H}_{2} \mathrm{O}+\mathrm{CO}_{2}$ \\
\hline $\mathrm{Ja}_{2} \mathrm{CO}_{3}$ & + & $\mathrm{H}^{+}$ & $----\cdots--->$ & $2 \mathrm{Na}^{+}+\mathrm{H}_{2} \mathrm{O}+\mathrm{CO}_{2}$ \\
\hline
\end{tabular}

All of these reactions are $100 \%$ complete at the end of the acid addition to the SRAT and the subsequent reflux period.

Reaction with Sodium Nitrite

$2 \mathrm{H}^{+}+2 \mathrm{NO}_{2}^{-}+2 \mathrm{H}_{2} \mathrm{O}+2 \mathrm{NO}$ 
Nuclear Criticality Safety Analysis

Summary Report: The S-Area

Defense Waste Processing Facility

WSRC-RP-94-396

Rev. 0

Page 44 of 52

The following reaction occurs after the addition of PHA,

$2 \mathrm{H}^{+}+2 \mathrm{NO}_{2}^{-}+\mathrm{HCOOH}+\cdots--\cdot-->\mathrm{CO}_{2}+2 \mathrm{H}_{2} \mathrm{O}+2 \mathrm{NO}$

$\underline{\text { Reduction of } \mathrm{MnO}_{2}}$

$\mathrm{MnO}_{2}+\mathrm{HCOOH}+2 \mathrm{H}^{+}+\ldots-\ldots-\cdots \mathrm{CO}_{2}+\mathrm{Mn}^{++}+2 \mathrm{H}_{2} \mathrm{O}$

Melter operating experience indicates that significant foaming in the melter would not occur when this reaction is approximately $50 \%$ complete. However, lower yield may also be satisfactory. $40 \%$ yield is used as the calculation basis for the nitric acid requirement. 26

$\underline{\text { Reduction of } \mathrm{HgO}}$

$\mathrm{HgO}+\mathrm{HCOOH}+\ldots-\ldots+-.--\mathrm{Hg}_{2} \mathrm{O}+\mathrm{CO}_{2}$

The yield for this reaction is $100 \%$. The DWPF design basis requires at least $33 \%$ of mercury to be steam stripped from the sludge slurry at the end of the SRAT cycle.

There are also other reactions which destroy formic acid (or formate) from the PHA slurry to produce hydrogen gas and ammonium ions due to catalytic effects of noble metals.

The SRAT sludge slurry product is then transferred to the Slurry Mix Evaporator (SME) tank for the addition of glass forming frit. There is no chemical processing in the SME. The major processing steps are basically evaporation of water to make room for the glass frit addition. The resulting sludge frit PHA slurry is fed to the glass melter in the Melt Cell. Occasionally, the SME product slurry has to be remediated for waste glass quality by addition of sodium hydroxide, potassium nitrate, or glass frit, or a combination of them. Except for glass frit, the sodium hydroxide and potassium nitrate are soluble in the SME aqueous content. The final acceptable SME sludge/frit slurry is then transferred to the Melter Feed Tank (MFT) in the Melt Cell. 
Nuclear Criticality Safety Analysis

Summary Report: The S-Area

Defense Waste Processing Facility
WSRC-RP-94-396

Rev. 0

Page 45 of 52

\section{Melt Cell}

The waste sludge/frit slurry from the MFT is continuously fed to the Melter, which is operating at $1150^{\circ} \mathrm{C}$. There are major redox reactions in the Melter, which ultimately determine the durability and other physical properties of the waste glass product. The melter operation can be simply viewed as a water evaporating operation, where all of the water will be driven off. All of the other chemical species will remain in the molten glass, and will be subsequently immobilized in the borosilicate glass matrix for long term storage and disposal. 
Nuclear Criticality Safety Analysis

Summary Report: The S-Area

WSRC-RP-94-396

Defense Waste Processing Facility

Rev. 0

Page 46 of 52

Appendix B

Current SRS SludgeWaste Tank Inventory. 25

\begin{tabular}{|c|c|c|c|c|c|c|c|c|}
\hline $\begin{array}{c}\text { TANK } \\
\#\end{array}$ & $\begin{array}{c}\text { Total } \\
\text { Uranium } \\
(\mathbf{K g})\end{array}$ & $\begin{array}{c}\text { U-233 } \\
\text { (g) }\end{array}$ & $\begin{array}{c}\text { U-235 } \\
\text { (g) }\end{array}$ & $\begin{array}{c}\text { Pu-239 } \\
\text { (g) }\end{array}$ & $\begin{array}{l}\text { Pu-241 } \\
\text { (g) }\end{array}$ & $\begin{array}{c}\mathrm{Fe}(\mathrm{OH}) 3 \\
(\mathrm{Kg})\end{array}$ & $\begin{array}{c}\mathrm{MnO2} \\
(\mathrm{Kg})\end{array}$ & $\begin{array}{l}\text { Uranium } \\
\text { Enrichment }\end{array}$ \\
\hline 1 & 1323 & 0 & 8167 & 2139 & 3 & 3729 & 1878 & $0.62 \%$ \\
\hline 2 & 61 & 0 & 376 & 318 & 0 & 593 & 490 & $0.62 \%$ \\
\hline 3 & 152 & 0 & 939 & 383 & 0 & 1051 & 1038 & $0.62 \%$ \\
\hline 4 & 10016 & 0 & 35951 & 9616 & 18 & 21300 & 6492 & $0.36 \%$ \\
\hline 5 & 7474 & 0 & 48448 & 7755 & 13 & 24201 & 5455 & $0.65 \%$ \\
\hline 6 & 7425 & 0 & 30763 & 4095 & 16 & 10086 & 2381 & $0.41 \%$ \\
\hline 7 & 27414 & 0 & 175553 & 58978 & 102 & 171211 & 31030 & $0.64 \%$ \\
\hline 8 & 20771 & 0 & 69757 & 31858 & 85 & 72338 & 6712 & $0.34 \%$ \\
\hline 9 & 89 & 0 & 546 & 100 & 0 & 563 & 449 & $0.61 \%$ \\
\hline 10 & 17 & 0 & 106 & 51 & 0 & 97 & 119 & $0.62 \%$ \\
\hline 11 & 194 & 211 & 14631 & 23942 & 868 & 32181 & 3832 & $7.67 \%$ \\
\hline 12 & 2092 & 3955 & 31211 & 37262 & 527 & 31526 & 23077 & $1.68 \%$ \\
\hline 13 & 5606 & 4194 & 72487 & 23452 & 172 & 199837 & 25809 & $1.37 \%$ \\
\hline 14 & 239 & 39 & 1920 & 972 & 2 & 1163 & 1116 & $0.82 \%$ \\
\hline 15 & 40 & 1433 & 28308 & 19588 & 199 & 28848 & 6644 & $74.22 \%$ \\
\hline 17 & 251 & 0 & 625 & 792 & 3 & 4590 & 177 & $0.25 \%$ \\
\hline 18 & 466 & 0 & 1454 & 1550 & 4 & 7360 & 284 & $0.31 \%$ \\
\hline 19 & 55 & 0 & 94 & 174 & 0 & 1496 & 57 & $0.17 \%$ \\
\hline 21 & 8 & 18 & 1091 & 18 & 0 & 4510 & 4 & $13.86 \%$ \\
\hline 22 & 32 & 111 & 2734 & 0 & 0 & 9479 & 0 & $8.89 \%$ \\
\hline 26 & 6034 & 0 & 10241 & 38507 & 189 & 67112 & 5296 & $0.17 \%$ \\
\hline 30 & 0.24 & 0 & 150 & 493 & 37 & 68 & 30 & $62.30 \%$ \\
\hline 32 & 102 & 0 & 18362 & 56814 & 2917 & 47980 & 5678 & $18.00 \%$ \\
\hline 33 & 25726 & 0 & 43659 & 16612 & 79 & 14204 & 0 & $0.17 \%$ \\
\hline 34 & 24056 & 0 & 52761 & 20924 & 98 & 22305 & 9 & $0.22 \%$ \\
\hline 35 & 139 & 0 & 21852 & 52966 & 3174 & 33099 & 4568 & $15.72 \%$ \\
\hline 36 & 0.24 & 0 & 65 & 77 & 4 & 20 & 7 & $26.81 \%$ \\
\hline 39 & 71 & 0 & 23438 & 82302 & 5589 & 11203 & 5003 & $33.01 \%$ \\
\hline 40 & 4838 & 148 & 18611 & 15960 & 46 & 88422 & 2928 & $0.39 \%$ \\
\hline 41 & 0.15 & 0 & 66 & 0 & 0 & 1673 & 0 & $43.51 \%$ \\
\hline 42 & 3477 & 777 & 33336 & 20631 & 128 & 93230 & 5225 & $0.98 \%$ \\
\hline 43 & 42 & 0 & 13713 & 1696 & 96 & 36518 & 109 & $32.65 \%$ \\
\hline 47 & 4223 & 0 & 8629 & 36412 & 160 & 61857 & 4495 & $0.20 \%$ \\
\hline 51 & 6887 & 79 & 24640 & 22864 & 66 & 121025 & 4196 & $0.36 \%$ \\
\hline
\end{tabular}




\section{Appendix C}

Planned Major DWPF Sludge Batches.

\begin{tabular}{c|cccccccc}
$\begin{array}{c}\text { (Note 1) } \\
\text { DWPF } \\
\text { Batch } \\
\#\end{array}$ & $\begin{array}{c}\text { Uranium } \\
\text { (Kg) }\end{array}$ & $\begin{array}{c}\text { U-233 } \\
(\mathrm{g})\end{array}$ & $\begin{array}{c}\text { U-235 } \\
\text { (g) }\end{array}$ & $\begin{array}{c}\text { Pu-239 } \\
(\mathrm{g})\end{array}$ & $\begin{array}{c}\text { Pu-241 } \\
(\mathbf{g})\end{array}$ & $\begin{array}{c}\mathbf{F e}(\mathbf{O H}) 3 \\
(\mathbf{K g})\end{array}$ & $\begin{array}{c}\text { MnO2 } \\
(\mathbf{K g})\end{array}$ & $\begin{array}{c}\text { Uranium } \\
\text { Enrichment }\end{array}$ \\
\hline 1 & 10364 & 856 & 57975 & 43495 & 194 & 214256 & 9421 & $0.57 \%$ \\
2 & 21005 & 1644 & 112696 & 75388 & 1153 & 133368 & 17188 & $0.54 \%$ \\
3 & 43984 & 3994 & 253264 & 143241 & 808 & 287058 & 66209 & $0.58 \%$ \\
4 & 26784 & 4194 & 184442 & 126927 & 3565 & 334995 & 44078 & $0.70 \%$ \\
5 & 51533 & 0 & 161414 & 181187 & 8783 & 137583 & 14205 & $-0.34 \%$ \\
6 & 812 & 129 & 5997 & 2533 & 8 & 27435 & 523 & $0.75 \%$
\end{tabular}

Note 1: Reference 33 provides the sludge removal sequence to determine the inventory of each DWPF batches using historical data.

Batch 1 comes from Tank 42 and Tank 51.

Batch 2 will come from Tanks 8, 11, and 15.

Batch 3 will come from Tanks 4, 7, 12, 14, and 47.

Batch 4 will come from Tanks 5, 6, 9, 10, 13, 26, and 35.

Batch 5 will come from Tanks 1, 2, 3, 32, 33, 34, 39, and 43.

Batch 6 will come from Tanks 17, 18, 19, 21, and 22.

Note 2: Batch 6 is also supposed to include Tanks 23 and 24 which currently contain only small volumes of sludge 50 . 
Nuclear Criticality Safety Analysis

Summary Report: The S-Area

Defense Waste Processing Facility
WSRC-RP-94-396

Rev. 0

Page 48 of 52

\section{References}

1. DOE Order 5480.24, "Nuclear Criticality Safety," August 12, 1992.

2. ANSI/ANS 8.1-1983, "Nuclear Criticality Safety in Operations with Fissionable Materials Outside Reactors."

3. DOE Order 5480.23, "Nuclear Safety Analysis Reports," March 10, 1994.

4. DOE-STD-1027-92, "DOE Standard Hazard Categorization and Accident Analysis Technique with DOE Order 5480.23, Nuclear Safety Analysis Reports," December 1992.

5. J. S. Clemmons and A. Q. Goslen, "NCSA WM-92-3 Minimum Safe Ratios of $\mathrm{Fe}$ and $\mathrm{Mn}$ to U-235 in an Infinite System (U)," WERHLE-921143, September 18, 1992.

6. J. S. Clemmons and A. Q. Goslen, "NCSA WM-92-5 Minimum Safe Ratios of $\mathrm{Fe}$ and $\mathrm{Mn}$ to Pu-239 in an Infinite System (U)," WERHLE-921353, November 25, 1992.

7. D. T. Hobbs and S. D. Fleischman, "Fissile Solubility and Monosodium Titanate Loading Tests," WSRC-RP-92-1273, February 12, 1993.

8. A. S. Choi, "Material Balance Tables for the DWPF Coupled Feed Flowsheet with Batch 1 Sludge (U)," WSRC-TR-93-202, Rev. 0, Draft, 1993.

9. ANSI/ANS-8.15-1981, "Nuclear Criticality Control of Special Actinide Elements," November 9, 1981.

10. Special Nuclear Material Accountability Records (Classified: Secret).

11. B. C. Ha, D. M. Ferrara, and N. E. Bibler, "Formic Acid Boiling Experiments of Monosodium Titanate Containing Adsorbed Depleted Uranium (U)," WSRC-RP-94-1133, 1994. 
Nuclear Criticality Safety Analysis

Summary Report: The S-Area

WSRC-RP-94-396

Defense Waste Processing Facility

Rev. 0

Page 49 of 52

12. W. F. Linke, Solubilities Inorganic and Metal-Organic Compounds K-Z, Volume II, Fourth Edition, Van Nostrand, New York, 1965, page 1598-1599.

13. M. K. Andrews and N. E. Bibler, "Radioactive Demonstration of DWPF Product Control Strategy," ACS Ceramic Transactions: Environmental and Waste Management Issues in the Ceramic Industry, Vol. 39, pg. 205-211, 1994.

14. N. E. Bibler, W. F. Kinard, R. A. Dewberry, and C. J. Coleman, "A Method for the Determination of Waste Acceptance Radionuclides in DWPF Glass and Demonstration of that Method using SRS Tank 51 Radioactive Sludge and Glass," WSRC-TR-940505, October 20, 1994.

15. M. C. Chandler, "Nuclear Criticality Safety Bounding Analysis for the In-Tank-Precipitation (ITP) Process (U)," WSRC-TR-93-171, Rev. 0, March 12, 1993.

16. J. S. Clemmons, "Nuclear Safety of Extended Sludge Processing on Tank 42 and Tank 51 Sludge (DWPF Sludge Feed Batch One) (U)," WSRC-TR-93-115, Rev. 0, February 26, 1993.

17. J. S. Clemmons, "Assessment of Criticality Safety Parameters Based on Estimated Waste Tank Sludge Content," HLW-HLE-940388, 1994.

18. T. G. Williamson, "Nuclear Criticality Safety Evaluation DWPF Late Wash Facility, Salt Processing Cell, and Chemical Processing Cell," EPD-CTG-940037, October 1994.

19. T. G. Williamson, "Nuclear Criticality Safety Evaluation DWPF Melter," SRT-CMA-930039, July 1993.

20. D. D. Walker, "Process Requirements for the In-Tank Precipitation Process," WSRC-IM-91-63, Rev. 0, September 21, 1992.

21. C. E. Bess, "'Nuclear Criticality Safety Bounding Analysis for the In-Tank-Precipitation (ITP) Process, Impacted by Fissile 
Nuclear Criticality Safety Analysis

Summary Report: The S-Area

WSRC-RP-94-396

Defense Waste Processing Facility

Rev. 0

Page 50 of 52

Isotopic Weight Fractions (U)," WSRC-TR-94-004 Rev. 0, April 22, 1994.

22. D. T. Hobbs, T. B. Edwards, and S. D. Fleischman, "Solubility of Plutonium and Uranium in Alkaline Salt Solutions (U)," WSRCTR-93-056, February 12, 1993.

23. D. D. Walker, "Material Balance for the In-Tank Precipitation Process with Late Washing," WSRC-RP-92-396, April 16, 1992.

24. D. D. Walker and B. A. Hamm, "Material Balance and Planned Operating Schedule for the In-Tank Process" WSRC-RP-891303, December 27, 1989.

25. H. Tran, "Estimated Sludge Inventory for Individual Tanks," WSRC-TR-94-0191, May 1994.

26. C. W. Hsu, "Defense Waste Processing Facility Nitric Acid Requirement for Treating Sludge (U)," WSRC-RP-92-1056, September 4, 1992.

27. C. J. Coleman, N. E. Bibler, D. M. Ferrara, and S. F. Siegwald, "Reactions of Formic and Nitric Acids with Savannah River Site Radioactive HLW Sludges in the DWPF Pretreatment Steps," WM'94, Proceeding of the Symposium on Waste Management, 1994.

28. C. J. Coleman, N. E. Bibler, and R. A. Dewberry, "Analysis of High Level Radioactive Glasses and Sludges at the Savannah River Site," Proceedings of Waste Management '90, Tucson, AZ, pp 651-657.

29. N. E. Bibler, S. B. Wyrick, R. A. Dewberry, and C. J. Coleman, "Uranium and Plutonium Concentrations and Isotopics in Tank 42 Sludge Slurry (U)," WSRC-RP-93-262, February 25, 1993.

30. W. S. Cavin, "Separations Waste Sludge Spreadsheet (U)," WSRCTR-93-135, July 28, 1993.

31. W. S. Cavin and A. T. Crum, "Fresh Waste Receipts (U)," WSRCTR-93-426, Rev. 1, January 21, 1994. 
Nuclear Criticality Safety Analysis

Summary Report: The S-Area

WSRC-RP-94-396

Defense Waste Processing Facility

Rev. 0

Page 51 of 52

32. W. S. Cavin and A. T. Crum, "Waste'Transfers and Miscellaneous Additions (U)," WSRC-TR-93-425, Rev. 1, January 21, 1994.

33. HLW-OVP-94-0077, " HLW System Plan Revision 3," May 1994.

34. B. C. Ha, "Assessment of Nuclear Safety and Nuclear Criticality Potential in the Defense Waste Processing Facility (U)," WSRCRP-93-692, Rev. 0, 1993.

35. J. S. Clemmons, "Effect of ESP on Waste Tank Sludge U, Pu, Fe, and Mn Content," WER-HLE-930561, February 10,1993.

36. M. S. Hay and N. E. Bibler, "Characterization and Sludge Washing Studies of Tank 42H," WSRC-RP-94-730, July 27, 1994.

37. L. F. Landon, "Program to Address Present Problems with Salt Processing Cell Decanters and Reactor Fouling," DPST-88-851, September 20, 1988.

38. L. F. Landon/PHEF Task Team, "Executive Summary of HAN Precipitate Hydrolysis Experimental Facility," WSRC-RP-89-01, April 3, 1989.

39. WSRC-RP-92-1186, "Basic Data Report Defense Waste Processing Facility Sludge Plant Savannah River Site 200-S Area (U)," July 1992.

40. R. E. Eibling, "Plutonium Accumulation in the Slurry Receipt Adjustment Tank," DPST-82-766, August 10, 1982.

41. B. C. Ha, N. E. Bibler, D. M. Ferrara, "Plutonium in the Mercury of the SRAT product," SRT-GTC-93-0061, June 1993.

42. H. K. Clark, "Nuclear Criticality Safety Assessment of Defense Waste Processing Facility," DPST-82-965, November 1, 1982.

43. P. D. Soper, "Plutonium-239 Accumulation in the DWPF Melter," DPST-82-673, July 1, 1982. 
Nuclear Criticality Safety Analysis

Summary Report: The S-Area

Defense Waste Processing Facility
WSRC-RP-94-396

Rev. 0

Page 52 of 52

44. D. G. Karraker, "Actinide Valences in Borosilicate Glass,". J. of Am. Ceramic Soc, Vol. 65, No. 1, pg. 53-55, January 1993.

45. M. J. Plodinec and J. R. Wiley, "Evaluation of Glass as a Matrix for Solidifying Savannah River Plant Waste: Properties of Glasses Containing Li2O," DP-1498, February 1979.

46. A. Seidel, Solubilities of Inorganic and Metallic Organic Compounds, Fourth Edition, Van Nostrand, New York, 1965, Volume II, page 558.

47. A. Seidel, Solubilities of Inorganic and Metallic Organic Compounds. Third Edition, Van Nostrand, New York, 1940, Volume I, page 1004.

48. A. Seidel, Solubilities of Inorganic and Metallic Organic Compounds, Fourth Edition, Van Nostrand, New York, 1965, Volume I, pg. 1038-1039.

49. I. M. Kolthoff and E. B. Sandell, Textbook of Quantitive Inorganic Analysis, third edition, The MacMillan Company, 1952, pg. 122-137.

50. WSRC-RP-93-78-8B, "Waste Management Monthly Data Record (U)," August 1993. 
WSRC-RP-94-396

Revision 0

\section{Distribution:}

L. M. Papouchado, 773-A

E. F. Duhn, 773-A

M. J. Plodinec, 773-A

L. F. Landon, 704-T

D. A. Crowley, 704-1T

J. T. Carter, 704-25S

K. R. Yates, 992 W-2

W. S. Durant, 992 W-1

H. H. Elder, 704-S

$\sim$ C. E. Apperson, 773-24A

A. G. Sarrack, 992-1W

T. G. Williamson, 773-42A

N. H. Kuehn, 704-T

W. T. Goldston, 704-S

W. R. Mangiante, 992-1W

J. R. Chandler, 773-24A

Advanced Waste Disposal Tech. \&

Waste Compliance Technology (19)
E. W. Holtzscheiter, 773-A

J. F. Ortaldo, 704-S

J. R. Harbour, 773-43A

C. T. Randall, 704-T

S. A. Budenstein, 704-1T

R. W. Rathbun, 786-1A

B. C. Ha, 773-A

R. E. Eibling, 704-T

J. R. Fowler, 704-Z

- R. A. Jacobs, 704-T

J. F. Mincey, 773-22A

N. E. Bibler, 773-A

D. A. Sharp, $992 \mathrm{~W}-1$

- M. C. Chandler, 703-H

J. W. Ray, 704-35S

W. D. Kimball, 704-S

- R. F. Bradley, 992-2W

TIM, 703-43A 